\title{
Autocratic Transitions and Growth
}

\author{
Tommaso Nannicini \\ Roberto Ricciuti
}

\author{
CESIFO WORKING PAPER NO. 2967 \\ CATEGORY 6: FisCAL POLICY, MACROECONOMICS AND GROWTH \\ FEBRUARY 2010
}
An electronic version of the paper may be downloaded
- from the SSRN website:
www.SSRN.com
- from the RePEc website:
- from the CESifo website:
www.RePEc.org
www.CESifo-group.org/wp




\title{
Autocratic Transitions and Growth
}

\begin{abstract}
In this paper we use a transparent statistical methodology - synthetic control methods - to implement data-driven comparative studies about the impact of autocratic transition on real per capita GDP. The applied methodology compares the growth of countries that experienced a transition to autocracy with the growth of a convex combination of similar countries that remained democratic, and it accommodates for the time-varying impact of unobservable heterogeneity. To implement this statistical framework, in a panel of 160 countries, we focus on 14 episodes of transition from democracy to autocracy. We find that the effects of autocratic transitions come in all shapes and sizes, since our data are split in almost equal parts between insignificant, negative, and positive effects. We also find that negative effects tend to get worse over time, and that African countries are badly affected by the autocratic transition possibly because of a resource curse.
\end{abstract}

JEL-Code: C21, C23, O43, O57.

Keywords: autocracy, democracy, growth, synthetic control methods.

\author{
Tommaso Nannicini \\ Bocconi University \\ Department of Economics \\ Via Roentgen \\ Italy - 20136 Milan \\ tommaso.nannicini@unibocconi.it
}

\author{
Roberto Ricciuti \\ University of Florence \\ Department of Economics \\ Via delle Pandette, 21 \\ Italy- 50127 Florence (FI) \\ roberto.ricciuti@unifi.it
}

We thank Guido Tabellini for sharing his data, as well as Lucia Spadaccini, Paolo Donatelli, and Jacopo Costa for excellent research assistance. 


\section{Introduction}

The economic growth literature has witnessed three main strands of research. The first, in the $50 \mathrm{~s}$ and 60s, was primarily concerned with the accumulation of capital, along Solovian lines. The second, in the $70 \mathrm{~s}$ and $80 \mathrm{~s}$, was concerned with the policies that governments may implement in order to achieve sustained growth. The third claims that institutions are the main determinants of growth. Probably the most basic institutional feature concerns the democratic vs. autocratic nature of the state. With this respect, the results of the literature have been disappointing, uncovering a very weak relationship between democracy and growth.

Recently, Persson and Tabellini $(2006,2008)$ have explored several issues on the relationship between democracy and growth emphasizing the role of heterogeneity by using a semi-parametric methodology (i.e., diff-in-diff propensity score matching) that relaxes linearity and is therefore well suited for the study of this feature. They find much larger effects than those commonly found in the literature. In particular, transitions from democracy to autocracy have an average negative effect on growth of about 2 percentage points, which implies a $45 \%$ income drop at the end of their sample.

In this paper, we apply the synthetic control method proposed by Abadie and Gardeazabal (2003) and Abadie et al. (2010) to perform data-driven comparative case studies. We evaluate the effect of a binary treatment - autocratic transition - on real per capita income in a panel framework. The proposed methodology accounts for the presence of a time-varying impact of country unobservable characteristics, and therefore overcomes a major drawback of more standard estimators. Put in a different way, we ask whether the establishment of an autocratic regime in year $T_{0}$ will lead to higher growth in the years $T_{0}+i$ compared to similar countries that remained democratic. We therefore estimate the dynamic treatment effects of autocratic transition on growth over time (within a 10-year horizon). The advantage of this approach rests on the transparent construction of the counterfactual outcome of the treated country, that is, a linear combination of untreated countries: the synthetic control. The comparison countries that form the synthetic control (and their relative weights) are selected based on their similarity to the treated country before the treatment takes place, both with respect to past realizations of the outcome and the standard covariates used in the growth literature. The transparency of this (matching) algorithm safeguards against drawing inference from (disputable) parametric extrapolation.

To anchor our results to the existing literature, we use the data set by Persson and Tabellini $(2006,2008)$. Because the synthetic control method is best suited for sharp regime 
changes, we define as autocratic transition - the treatment of interest - a drop of at least 10 points in the Polity IV Index (Marshall and Jaggers, 2009) making a country cross the democratic threshold at zero. We are, therefore, able to identify 14 autocratic transitions in our data, which range from 1963 to 2000 . Note that the diff-in-diff matching results by Persson and Tabellini (2008) are based on 18 autocratic transitions satisfying their common support condition, 10 of which overlap with our set of feasible country experiments.

We find that the effects of autocracy transitions come in all shapes and sizes since our dataset is split in almost equal parts between insignificant, negative, and positive effects. We also find that negative effects tend to get worse over time, and that African countries are badly affected by these transitions, possibly because of a resource curse.

The paper is organized as follows. Section 2 reviews the literature on the effects of both democracy and autocracy on growth. Section 3 outlines the statistical methodology. Section 4 presents the data and discusses the empirical results. Section 5 concludes.

\section{Literature review}

\subsection{Democracy and growth}

The literature on democracy and growth has uncovered an extremely weak (and more often negative) relationship between these variables. We can distinguish between two strands of empirical literature: the first employing cross-sectional data, and the second using panel data. ${ }^{1}$ There is also a small literature on the effects of autocracy on growth that we take into account.

Barro (1996) analyses a cross-section of about 100 countries from 1960 to 1990 . The dependent variables are the growth rate of real per capita GDP over 1965-1975, 1975-1985, 1985-1990 using a system of three equations. Estimations are done by instrumental variables: the instruments are the five-year earlier value of $\log$ GDP, the actual values of schooling, lifeexpectancy, rule of law and terms of trade, and the earlier values of the other variables (which include the fertility rate, government consumption ratio, public educational spending ratio, black market premium, investment ratio) involved in the estimations. Democracy is measured by Bollen (1960) and the Gastil Index. The estimated coefficient of democracy is negative but

\footnotetext{
${ }^{1}$ For earlier surveys of economic theories on the link between democracy and growth, see Przeworski and Limongi (1993) and Przeworski et al. (2000); de Haan and Siermann (1995) provide a useful summary table of several studies reporting the conclusion, the employed measure of democracy, the critiques to that measure, and the econometric specification.
} 
not significantly different from zero, which Barro claims to be weakly negative. However, there is a positive nonlinear effect: the middle level of democracy is the most favorable to growth, the lowest comes second, and the highest third. According to Barro, maintenance of the rule of law, free markets, small government consumption and high human capital are the most important determinants of growth.

In a similar setting, Tavares and Wacziarg (2001) aim at distinguishing between the possible channels that link democracy and growth. They identify eight variables that can possibly be endogenous to democracy, therefore weakening Barro results: political instability, governance distortions, government size, human capital, income inequality, trade openness, and physical capital accumulation. To achieve identification a number of exogenous variables are used, belonging to the following groups: cultural, demographic, gravity, historical, log of income per capita and its squared value. A system of eight simultaneous equations is estimated via three-stage least squares. Data are five-year averages of the variables involved in the analysis for 65 countries over 1970-1989. They find that the overall effect of democracy on growth is negative. This result is the outcome of a positive effect growth via human capital accumulation and reduction of income inequality, and a negative effect of reduced physical capital accumulation and increased government consumption.

Starting from the inconclusive results of this literature, Aghion et al. (2007) decompose the effect of democracy on several sectors, characterized by different productivity levels and patterns of technological development. Using UNIDO data for 28 manufacturing sectors for 180 countries for the period 1963 to 2003, they find that democratic institutions and political rights enhance growth of sectors close to the technological frontier. Second, they notice that political rights are associated with freedom of entry and the latter is especially important for sectors close to the technological frontier. Third, more advanced economies benefit more from democratic institutions and therefore the demand for democracy should increase with the level of per capita income in a country.

A more recent wave of research applies panel data with a diff-in-diff methodology. ${ }^{2}$ In particular, Giavazzi and Tabellini (2005) and Persson and Tabellini (2006, 2008) apply this methodology on about 160 countries over the period 1960-2000, exploring issues ranging

\footnotetext{
${ }^{2}$ Note that this methodology considers as treated those countries that underwent a single transition from autocracy to democracy, and as control those countries that remained autocracies. The methodology rests on two assumptions. First, without any regime change, growth in treated countries should counterfactually have been the same as in control countries, other things being equal. Second, heterogeneity in the effects of democracy should be unrelated with the occurrence of democracy itself.
} 
from the relationship between political and economic liberalizations to the effect of democracy on growth, taking into account (time-invariant) unobservable heterogeneity. In general, these results seem more favorable to a positive link between democracy and growth. Their treatment definition is similar to ours, as they focus on regime change rather than the simple (cross-sectional) comparison of different regimes.

Giavazzi and Tabellini (2005) study the timing of political and economic liberalizations. They find that political reforms cause economic liberalizations, but they cannot rule out feedback effects in both directions. Moreover, countries that first liberalize and then become democracies do much better than countries that pursue the opposite sequence. Persson and Tabellini (2006) report that a new parliamentary democracy is more prone to pursue economic liberalizations than a new presidential democracy but, given the results of Giavazzi and Tabellini (2005), liberalizations following democratizations have weaker effects on growth. Parliamentary democracies raise government consumption much more than presidential democracies, reducing growth. Spending effects of the electoral system are less pronounced and do not affect growth.

Persson and Tabellini (2009) note that, if democracy has a positive effect on growth and long-run income, it also raises the returns to investment. Because investment reacts to expected returns, expected, and not just actual, regime change affects growth. Growth will accelerate before an anticipated democratization, and decelerate well before an anticipated coup. In their model the probability of regime change depends on a country's "democratic capital". This capital is assumed to accumulate in years of democracy and in countries with democratic neighbors, but to depreciate under autocracy. The results are consistent with the model in the usual sample, and also in another one dating from 1850 to 2000.

Persson and Tabellini (2008) explore issues on the relationship between democracy and growth emphasizing the role of heterogeneity. They combine the above mentioned method with the propensity score matching estimator. This semi-parametric methodology relaxes linearity and it is therefore well suited for the study of heterogeneity, an issue already in the background in the early studies on democracy and growth. ${ }^{3}$ The cost is a loss in the efficiency of the estimates. They also find that the discrepancies relative to the parametric

\footnotetext{
${ }^{3}$ Diff-in-diff propensity score matching, similarly to the synthetic control method we apply in this paper (see Section 3), relaxes the linearity assumption of the standard diff-in-diff and, by transparently checking for the existence of a common support between treated and control units, avoid drawing inference from parametric extrapolation. However, this methodology, unlike ours, still rely on the assumption that the impact of unobservable confounders must be time-invariant.
} 
results are driven by large differences in the composition of the treatment and control groups, making linearity a doubtful assumption. Moving to the results, they uncover a positive but insignificant effect of transitions from autocracy to democracy.

Papaioannou and Siourounis (2008a) consider democratization processes for about 65 countries over 1960-2000. They employ an event study approach and analyze growth before and after democratizations. The dynamic panel estimates imply that democratizations are associated with a one percent increase in real per capita growth. Furthermore, during the transition, growth is slow and even negative; after the third post-democratization year, growth peaks and stabilizes at a higher level. ${ }^{4}$

Acemoglu et al. (2008) are interested in the causal relationship between income and democracy, that is, the "modernization hypothesis": the increase in industrialization, urbanization, wealth and education lead to more democracy. They employ two strategies: first use country fixed effects to get rid of country specific characteristics that may affect both variables. Second, they apply an instrumental variables strategy, by using past savings rates and changes in the incomes of trading partners. The estimated coefficients are not significantly different from zero both in the post-WWII era and over 100 years. The authors claim that the positive "correlation between changes in income and democracy is caused some societies have embarked on divergent development paths at some critical junctures during the past 500 years" (Acemoglu et al., 2008: 813). They identify these critical junctures with factors dating back 500 years ago (constraints on the executive, year of independence, religious affiliation). In a companion work, Acemoglu et al. (2010) look at the effect of income on transition to and from democracy. Again, they show that in a linear model with country fixed effects the correlation disappears, and this is also true in double hazard model for the simultaneous estimation of these two possible transitions.

\subsection{Autocracy and growth}

The economic analysis of the link between autocracy and growth is much less developed. The 'stationary bandits' theory of dictatorship (McGuire and Olson, 1996) explains different economic performances among autocracies in a model in which an autocrat maximizes his private consumption subject to the probability of staying in power. If a dictator expects to stay in power for a long period of time, he has an incentive to promote economic development

\footnotetext{
${ }^{4}$ See also Papaioannou and Siourounis (2008b).
} 
because he will then increase his private consumption through increased tax revenues resulting from economic growth. ${ }^{5}$

Besley and Kudamatsu (2008) develop a theory on the accountability of an autocrat with respect to the 'selectorate', the group of individuals on whom the leader depends to hold into power. Good policy is implemented when the selectorate removes poorly performing leaders. This happens if the selectorate's hold on power is not too dependent on a specific leader being in office. The paper empirically establishes cases where autocracy has been successful according to various criteria. They use these case studies to identify the selectorate in specific instances of successful autocracy, and also show that leadership turnover in successful autocracies is higher than in unsuccessful autocracies. Finally, they demonstrate by exploiting leadership deaths from natural causes - that successful autocracies appear to have found ways for selectorates to nominate successors without losing power.

In our framework, the treatment of interest is not autocracy per se but autocratic transition. The estimation of the effects of autocratic transition has been highlighted in a few papers. As mentioned above, Persson and Tabellini (2008) find an average negative effect on growth of leaving democracy of about 2 percentage points, and this accounts for a 45 percent loss of income over the sample. Furthermore, the transparency of their matching estimator in small samples allows them to identify the countries excluded from the estimation because outside of the common support (see Table 13.3b), as well as the estimated treatment effect for each episode of autocratic transition (see Figure 13.5). Among their 18 autocratic transitions, 4 experienced a mildly positive growth effect (i.e., below 2 percentage points), 7 a mildly negative effect, and 7 a strong negative effect (i.e., above 2 percentage points). Below we will come back in more detail to the comparison of our country results with those of their study.

Finally, note that Persson and Tabellini's (2008) results complement those of Minier (1998), who finds that countries that become less democratic grow more slowly than comparable countries. In contrast, Durham (1999) discovers that policy discretion associated with less democratic regimes inhibits investment in poorer countries. This stands out against the theory. Also, single-party dictatorships have higher investment ratios, but do not grow faster than party-less regimes.

\footnotetext{
${ }^{5}$ Grossman and Noh (1994) and Overland et al. (2005) assume that a dictator's survival is more likely if he adopts welfare-enhancing policies. Acemoglu and Robinson (2006) assume that welfare-enhancing policies directly reduce the dictator's survival prospects while increasing the survival chance through competition for power with a challenger. Consequently, successful autocrats are either those who are secure enough or those who face tough competition from a challenger.
} 


\section{Methodology}

In this paper, we apply the synthetic control method (SCM) - developed by Abadie and Gardeazabal (2003) and extended in Abadie et al. (2010) - to the investigation of the effects of autocratic transitions on growth. Under this approach, a weighted combination of potential comparison countries - the synthetic control - is constructed to approximate the most relevant characteristics of the country affected by the intervention. After a regime change (i.e., a transition to autocracy) takes place in a given country, the SCM can be used to estimate the counterfactual situation of this country in the absence of the regime change by looking at the outcome trend of the synthetic control. In our empirical application, we consider countries that become autocracies in a particular year and compare them with countries that remain democratic for at least 10 more years (or until the end of the sample).

To summarize the SCM approach, it is useful to reason in terms of potential outcomes in a panel set-up. Assume that we observe a panel of $I_{C}+1$ countries over $T$ periods. Only country $i$ receives the treatment (i.e., becomes an autocracy) at time $T_{0}<T$, while the remaining $I_{C}$ potential control countries remain democratic. The treatment effect for country $i$ at time $t$ can be defined as:

$$
\tau_{i t}=Y_{i t}(1)-Y_{i t}(0)=Y_{i t}-Y_{i t}(0)
$$

where $Y_{i t}(\mathrm{~T})$ stands for the potential outcome associated with $T \in\{0,1\}$, that is, real GDP per capita according to whether the economy is democratic or autocratic. The estimand of interest is the vector of dynamic treatment effects $\left(\tau_{i, T 0+1}, \ldots, \tau_{i, T}\right)$. For any period $t>T_{0}$, the estimation of the treatment effect is complicated by the missing counterfactual $Y_{i t}(0)$. Abadie et al. (2010) show how to identify the above dynamic treatment effects under the following general model for potential outcomes:

$$
\begin{aligned}
& Y_{j t}(0)=\delta_{t}+v_{j t} \\
& Y_{j t}(1)=\delta_{t}+\tau_{j t}+v_{j t} \\
& v_{j t}=Z_{j} \theta_{t}+\lambda_{t} \mu_{j}+\varepsilon_{i t}
\end{aligned}
$$


where $Z_{j}$ is a vector of relevant observed covariates that are not affected by the intervention and can be either time-invariant or time-varying; $\theta_{t}$ is a vector of parameters; $\mu_{j}$ is a countryspecific unobservable; $\lambda_{t}$ is an unknown common factor; and $\varepsilon_{j t}$ are transitory shocks with zero mean. In the present context, as all of the variables in $Z_{j}$ (initial GDP, population growth, secondary school enrollment, and investment share) refer to the pre-treatment period, the assumption that they are not affected by the treatment means that we have to rule out "anticipation" effects, i.e., that those variables immediately change in response to the anticipation of the future reform. Interestingly, the above model allows for the impact of unobservable country heterogeneity to vary with time, while, on the contrary, the usual diffin-diff (fixed-effects) specification imposes $\lambda_{t}$ to be constant across time.

Define $W=\left(\omega_{1}, \ldots, \omega_{I C}\right)^{\prime}$ as a generic $\left(\mathrm{I}_{\mathrm{C}} \times 1\right)$ vector of weights such that $\omega_{j} \geq 0$ and $\sum \omega_{j}=1$. Each value of $W$ represents a potential synthetic control for country $i$. Further define $\bar{Y}_{j}^{k}=\sum_{s=1}^{T o} k_{s} Y_{j s}$ as a generic linear combination of pre-treatment outcomes. Abadie et al. (2010) show that, as long as we can choose $W^{*}$ such that:

$$
\sum_{j=1}^{I c} \omega_{j}^{*} \bar{Y}_{j}^{k}=\bar{Y}_{i}^{k} \text { and } \sum_{j=1}^{I c} \omega_{j}^{*} Z_{j}=Z_{i}
$$

then

$$
\hat{\tau}_{i t}=Y_{i t}-\sum_{j=1}^{I c} \omega_{j}^{*} Y_{i t}
$$

is an unbiased estimator of $\tau_{i t}$. Condition (5) can hold exactly only if $\left(\bar{Y}_{i}^{k}, Z_{i}\right)$ belongs to the convex hull of $\left[\left(\bar{Y}_{1}^{k}, Z_{1}\right), \ldots,\left(\bar{Y}_{I c}^{k}, Z_{I c}\right)\right]$. Hence, the synthetic control $W^{*}$ is selected so that condition (5) holds approximately: the distance (or pseudo-distance) between the vector of pre-treatment characteristics of the treated country and the vector of the pre-treatment characteristics of the potential synthetic control is minimized with respect to $W^{*}$ and according to a specified metric. ${ }^{6}$ The deviation from condition (5) imposed by this implementation process, however, can be assessed in the data, and it should be shown as a complementary output of the analysis.

\footnotetext{
${ }^{6}$ In the empirical analysis, we use the (data-driven) distance metric calculated by the Stata routine synth, available at: www.people.fas.harvard.edu/_jhainm/software.htm. See Abadie et al. (2010) for technical details.
} 
In words, the synthetic control algorithm estimates the missing counterfactual as a weighted average of the outcomes of potential comparison countries (i.e., the synthetic control of the treated country). The weights are chosen so that the pre-treatment outcome and the covariates of the synthetic control are, on average, very similar to those of the treated country. This approach comes with the evident advantages of transparency (as the weights $W^{*}$ identify the countries that are used to estimate the counterfactual outcome of the country that became autocratic) and flexibility (as the set of $I_{C}$ potential controls can be appropriately restricted to make the underlying country comparisons more sensible). Furthermore, the SCM rests on identification assumptions that are weaker than those required by estimators commonly applied in the growth literature. As discussed above, while standard panel models can only control for confounding factors that are time invariant (fixed effects) or share a common trend (diff-in-diff), the model specified in equation (4) allows the effect of unobservable confounding factors to vary with time.

The only limitation of the SCM is that it does not allow to assess the significance of the results using standard (large-sample) inferential techniques, as the number of units in the control pool and the number of periods covered by the sample are usually quite small in comparative case studies like ours. As suggested by Abadie et al. (2010), however, placebo experiments can be implemented to draw inference. Below we implement cross-sectional placebo tests, which consist in applying the SCM to every country in the pool of potential controls; this is meant to assess whether the estimated effect for the treated country is large relative to the effect for a country chosen at random. In particular, placebo testing compares the estimated treatment effect for the country under investigation with all the (fake) treatment effects of the control countries, obtained from experiments where each control country is assumed to shift to autocracy in the same year of the treated country. If the estimated effect in the treated country is larger than those in most of the (fake) experiments, we can safely conclude that the baseline results are not just driven by random chance.

\section{Data and empirical results}

Moving to the data, we define as autocratic transition a drop of at least 10 points in the Polity IV Index (Marshall and Jaggers, 2009) by crossing the zero value. ${ }^{7}$ The value of zero is the standard threshold used in the literature to distinguish autocracies (negative values) from

\footnotetext{
${ }^{7}$ The "Polity Score" captures this regime authority spectrum on a 21-point scale ranging from -10 (hereditary monarchy) to +10 (consolidated democracy). Appendix I briefly describes the transitions in our sample.
} 
democracies (positive values). Starting with a data set of about 160 advanced and developing countries, we identify 14 episodes of transition to autocracy. The time-span runs from 1963 to 2000, but for each country we end up using different time-spans based on the year in which the transition took place. In fact, we use 1963 to $T_{0}$ as the pre-treatment period, and $T_{0}$ to $T_{0}+5$ (or $T_{0}+10$ ) as the post-treatment periods, where $T_{0}$ is the year of the autocratic transition. The set of control variables used in this paper includes those usually employed in the growth literature (initial GDP, investment as a share of GDP, population growth, and secondary school enrollment). The outcome - real per capita GDP - and the control variables are drawn from the data set by Persson and Tabellini (2006, 2008).

We now discuss each SCM country experiment and the associated placebo test, in order. In every experiment, the synthetic control is constructed from a worldwide pool of potential comparisons countries: that is, all eligible countries that are a democracy and remain so within ten years after the treatment at time $T_{0}{ }^{8}$ Tables 1 through 3 compare the treated countries and their synthetic control before and after the transitions by both per capita GDP and explanatory variables; the root mean squared prediction error (referred to the pretreatment fit) is also reported. Appendix II records the countries that are included in the donor pool of each SCM experiment, and Appendix III lists those that are indeed selected as components of the estimated synthetic control (in particular, those receiving a weight higher than 0.02). Figures 1 through 14 allow a graphical evaluation of the pre- and post-treatment fit by looking at the proximity of the outcome trends of each treated country (solid line) and its synthetic control (dashed line) before and after $T_{0}$ (i.e., on the left and on the right of the vertical dashed line, respectively). These figures - in the right panel - also report the placebo tests for each SCM experiment. There, the solid line represents the pre- and post-treatment outcome difference between the treated country and its synthetic control (i.e., the counterpart of the baseline estimation results reported in the left panel of each figure), while the dashed lines refer to the (fake) placebo experiments where each of the potential comparison countries is assumed to be the treated country at $T_{0}$.

Table 1 considers OECD and Asian economies. The economic consequence of the transition looks negligible for Greece, as its real per capita GDP five years later is very

\footnotetext{
${ }^{8}$ As a robustness check, in the spirit of Billmeier and Nannicini (2009b), for each treated country we also implemented an alternative experiment with a restricted donor pool of potential controls, including only countries in the same macro area of the treated country (OECD, Latin America, Asia, or Africa). For most experiments, the pre-treatment fit was quite poor; in the remaining feasible experiments, however, the findings were qualitatively similar to those presented in this section (results available upon request).
} 
similar, only slightly lower, to the outcome of the synthetic control. For Greece, the SCM experiment ends in 1974 (the year of a new transition from autocracy to democracy) and we therefore cannot report the outcome difference at $T_{0}+10$. Figure 1 shows that indeed the patterns of real per capita income in the treated country and synthetic control are very close to each other after $T_{0}$ (left panel), and the placebo test confirms the insignificance of the dynamic treatment effects (right panel). The autocratic transition in Greece had no significant impact on growth. This is in contrast with the result by Persson and Tabellini (2008, Figure 13.5), who estimate a strong negative treatment effect for Greece.

For the Philippines, we have almost no effect of the autocratic transition at $T_{0}+5(-0.01$ percentage points per year), and a small positive effect $(+0.59)$ ten years after the transition. In Figure 2, the synthetic control, in fact, shows an excellent fit of GDP both before and after the treatment. In the case of South Korea, the economic outcome of the transition is strongly positive in the first five years (+7.92 percentage point per year), and still sizable - albeit smaller - ten years after the coup (+3.98). Figure 3 illustrates this baseline result in the left panel, and the placebo test (right panel) confirms its robustness, because the post-treatment difference between South Korea and its synthetic control is the upper bound of all the differences in the (fake) placebo experiments. Pakistan presents a zero effect at $T_{0}+5$, and an extremely small effect at $T_{0}+10$. The insignificance of the effect is confirmed by the placebo test in the right panel of Figure 4. While the results for Philippines and Pakistan are not inconsistent with those by Persson and Tabellini (2008, Figure 13.5), we find a strong positive effect for South Korea, as opposed to a mildly negative effect in their study.

[Table 1 about here]

[Figures 1-4 about here]

Table 2 considers Latin American economies. Again, the effects of autocratic transitions are mixed. Panama displays a mildly positive effect five years after the coup $(+1.59)$, but this effect is strongly reduced at $T_{0}+10(+0.35)$. Figure 5 (left panel) shows that there is a growth acceleration immediately before the coup, a positive gap is then created with respect to similar countries that remained democratic, and from 1973 there is a growth reduction that brings Panama back on the same path of its synthetic control. The placebo test (right panel) confirms the robustness of the positive effect after five years (because it is greater than those of most fake experiments), but not after ten years. Similarly, a small positive effect is found for Uruguay $(+0.65)$, but in this case the effect is strongly reinforced 
in the longer run $\left(+3.10\right.$ at $\left.T_{0}+10\right)$. The placebo test in the right panel of Figure 7 confirms the positive effect for Uruguay, especially at the end of the post-treatment period.

[Table 2 about here]

[Figures 5-8 about here]

Peru and Chile, instead, exhibit negative effects. The former, five years after the coup, had a decline of -0.65 percentage points per year in GDP with respect to similar democratic countries, and this effect reached -3.10 after ten years. The latter experienced a decrease of 4.48 percentage points per year within five years, and -1.56 after ten years. The case of Chile is interesting because it is widely recognized as a success story in Latin America. Indeed, in Figure 8, we observe a serious drop in GDP in the years after the Pinochet takeover, due to the harsh fight between the junta and opponents, but this is followed by a strong recovery that brings the country back to the growth pattern of the other countries of the control, when freemarket policies are implemented. Yet, the recovery is far from complete at the end of the post-treatment period. The placebo tests for Peru (Figure 6) and Chile (Figure 8) confirm the baseline negative results, as the post-treatment outcome difference between the treated country and its synthetic control is the lower bound of all the differences in the (fake) placebo experiments. For Latin America, Persson and Tabellini (2008, figure 13.5) find the same qualitative result for Uruguay and Peru, but the opposite result for Chile and Panama.

Table 3 considers African economies. In the analysis of African countries, a more consistent and negative effect of autocratic transitions emerges, and this outcome tends to exacerbate over time. This is the case of Uganda ( -0.51 percentage points per year in the first five years after the transition, and -4.03 after ten years), Nigeria in 1984 (-3.12 and -3.81), Sierra Leone (-0.67 and -0.90$)$, and Gambia (-3.33 in five years). ${ }^{9}$ Mildly positive effects can be found in the transitions of Lesotho $(+0.52$ after five years and +2.93 after ten years $)$ and Nigeria $(+1.10$ and +0.91$)$. The placebo tests, however, do no always confirm the robustness of the above results. Only the negative results of the experiment for Gambia are clearly confirmed (see the right panel of Figure 14), because the, negative, post-treatment solid line is the lower bound of all the others. At a closer look, however, also Uganda and Nigeria in 1984 display a negative impact of the autocratic transition that is higher than those of most placebo experiments: this is only overshadowed - in Figure 9 and Figure 11, respectively - by a scale effect (that is, by the fact that some experiments involving richer countries display very large

\footnotetext{
${ }^{9}$ For Gambia we can only estimate GDP at $\mathrm{T}_{0}+5$ due to data limitations.
} 
differences in absolute terms). The results for Nigeria in 1966, Sierra Leone, and Lesotho are not robust to placebo testing. At the end of the day, all of the three African experiments that pass the placebo check show a negative impact of autocratic transition on growth.

The results for Africa are not easily comparable to those by Persson and Tabellini (2008) because Uganda, Lesotho, and Nigeria fall outside their common support and are therefore excluded by the estimates. Yet, their results for Sierra Leone are consistent with ours, while those for Gambia are not.

[Table 3 about here]

[Figures 9-14 about here]

The predominance of negative results in Africa can probably be related with the presence of a "resource curse" (see, among others, Sachs and Warner, 2001): when an oligarchy puts its hands over natural resources, it tends to extract rents form them and not to invest in the development of the country. In this respect, note that Nigeria is an oil-exporting country; Sierra Leone is a producer of diamonds, iron and bauxite; and Uganda sells abroad copper and cobalt. Gambia does not fall into this group, but the downturn was mainly due to economic sanctions set by the United Kingdom - its major trading partner - after the coup. Indirectly, this conclusion is reinforced by the circumstance that the first autocratic transition in Nigeria did not produce a negative effect on growth in a time in which oil was not yet a source of income for the government: it accounted for about 9\% of GDP in 1966 and for about 18\% in 1984 (Sala-i-Martin and Subramanian, 2003); in terms of total revenues it raised from $25 \%$ to $74 \%$ (Forrest, 1992). ${ }^{10}$ This is also consistent with Acemoglu et al. (2010), who claim that military coups are more likely in resource-rich countries.

\section{Conclusions}

In this paper we have analyzed the economic effect of leaving democracy in 14 episodes through a novel econometric approach for case studies, the synthetic control method. This approach allows taking into account a time-varying impact of country heterogeneity, and therefore overcomes a major drawback of more standard estimation techniques.

We get a number of interesting results. First, we find an almost equal split of our episodes between positive (South Korea, Panama, and Uruguay), negative (Chile, Peru,

\footnotetext{
${ }^{10}$ Lesotho became an important diamonds producer in the second half of the ' $70 \mathrm{~s}$.
} 
Uganda, Nigeria in 1984, and Gambia), and insignificant (Greece, Philippines, Pakistan, Nigeria in 1966, Sierra Leone, and Lesotho) consequences of autocratic transitions on economic growth. The negative effect shown by Chile is more the outcome of a very large medium-term fall in GDP that takes a long time to get recovered. With this respect, we find evidence contrasting with the (more pronounced) negative results found by Persson and Tabellini (2008). Second, when the effect of the transition is negative, it tends to worsen over time (with the significant exception of Chile), whereas the opposite is not usually true. Third, Africa has mainly negative effects on GDP possibly because of the interaction of the autocratic transition with a resource curse. 
Table 1: Predictor and outcome means for the autocracy treatment (OECD and Asia)

\begin{tabular}{|c|c|c|}
\hline & Greece 1967 & Synthetic Control \\
\hline Secondary school & 43 & 36.85 \\
\hline Population growth & 0.610 & 1.713 \\
\hline Investment share & 0.338 & 0.204 \\
\hline Average Pre-treatment GDP & 4185.7 & 4186.9 \\
\hline $\mathrm{GDP}$ at $\mathrm{T}_{\mathrm{o}}+5$ & 7670 & 7862.75 \\
\hline \multicolumn{3}{|l|}{ GDP at $T_{o}+10$} \\
\hline \multirow[t]{2}{*}{ RMSPE } & & 71.436 \\
\hline & Philippines 1972 & Synthetic Control \\
\hline Secondary school & 37.6 & 24.69 \\
\hline Population growth & 3.055 & 2.554 \\
\hline Investment share & 0.150 & 0.137 \\
\hline Average Pre-treatment GDP & 792.5 & 789.5 \\
\hline $\mathrm{GDP}$ at $\mathrm{T}_{\mathrm{o}}+5$ & 1070 & 1106.75 \\
\hline GDP at $T_{o}+10$ & 1180 & 1113.25 \\
\hline \multirow[t]{2}{*}{ RMSPE } & & 4.403 \\
\hline & South Korea 1972 & Synthetic Control \\
\hline Secondary school & 34.53 & 8.27 \\
\hline Population growth & 2.467 & 1.792 \\
\hline Investment share & 0.200 & 0.143 \\
\hline Average Pre-treatment GDP & 1640.83 & 1649.24 \\
\hline $\mathrm{GDP}$ at $\mathrm{T}_{\mathrm{o}}+5$ & 3460 & 2478.08 \\
\hline $\mathrm{GDP}$ at $\mathrm{T}_{\mathrm{o}}+10$ & 4170 & 2982.56 \\
\hline \multirow[t]{2}{*}{ RMSPE } & & 117.534 \\
\hline & Pakistan 1977 & Synthetic Control \\
\hline Secondary school & 12.62 & 22.76 \\
\hline Population growth & 2.903 & 2.216 \\
\hline Investment share & 0.138 & 0.126 \\
\hline Average Pre-treatment GDP & 238.76 & 239.42 \\
\hline $\mathrm{GDP}$ at $\mathrm{T}_{\mathrm{o}}+5$ & 346 & 348.35 \\
\hline GDP at $\mathrm{T}_{\mathrm{o}}+10$ & 410 & 422.69 \\
\hline RMSPE & & 14.587 \\
\hline
\end{tabular}

Notes: The table shows the mean values of predictors and outcomes for the treated country and the synthetic control, respectively. Predictors: pre-treatment real GDP per capita, secondary school enrollment, population growth, investment share. Outcome: real GDP per capita. The value of each predictor is averaged over the pre-treatment period. The values of the outcome refer to five years $\left(\mathrm{T}_{0}+5\right)$ and ten years $\left(T_{0}+10\right)$ after the treatment year $T_{0}$. RMSPE stands for Root Mean Squared Prediction Error. 
Table 2: Predictor and outcome means for the autocracy treatment (Latin America)

\begin{tabular}{|c|c|c|}
\hline & Panama 1968 & Synthetic Control \\
\hline Secondary school & 31.5 & 11.58 \\
\hline Population growth & 2.913 & 2.192 \\
\hline Investment share & 0.205 & 0.124 \\
\hline Average Pre-treatment GDP & 1763.75 & 1766.45 \\
\hline GDP at $\mathrm{T}_{\mathrm{o}}+5$ & 2600 & 2407.95 \\
\hline GDP at $T_{o}+10$ & 2690 & 2596.94 \\
\hline \multirow[t]{2}{*}{ RMSPE } & & 41.151 \\
\hline & Peru 1968 & Synthetic Control \\
\hline Secondary school & 20 & 26.16 \\
\hline Population growth & 2.842 & 2.661 \\
\hline Investment share & 0.352 & 0.128 \\
\hline Average Pre-treatment GDP & 2116.25 & 2116.131 \\
\hline GDP at $\mathrm{T}_{\mathrm{o}}+5$ & 2450 & 2849.94 \\
\hline GDP at $T_{o}+10$ & 2480 & 3633.14 \\
\hline \multirow[t]{2}{*}{ RMSPE } & & 23.549 \\
\hline & Uruguay 1972 & Synthetic Control \\
\hline Secondary school & 46.6 & 27.62 \\
\hline Population growth & 0.985 & 3.425 \\
\hline Investment share & 0.123 & 0.326 \\
\hline Average Pre-treatment GDP & 3859.16 & 3888.76 \\
\hline $\mathrm{GDP}$ at $\mathrm{T}_{\mathrm{o}}+5$ & 4470 & 4328.88 \\
\hline GDP at $T_{o}+10$ & 4710 & 3593.12 \\
\hline \multirow[t]{2}{*}{ RMSPE } & & 199.020 \\
\hline & Chile 1973 & Synthetic Control \\
\hline Secondary school & 31.8 & 23.8 \\
\hline Population growth & 2.160 & 2.98 \\
\hline Investment share & 0.188 & 0.164 \\
\hline Average Pre-treatment GDP & 2224.61 & 2218.96 \\
\hline $\mathrm{GDP}$ at $\mathrm{T}_{\mathrm{o}}+5$ & 2340 & 3015.79 \\
\hline $\mathrm{GDP}$ at $\mathrm{T}_{\mathrm{o}}+10$ & 2300 & 2726.61 \\
\hline RMSPE & & 46.154 \\
\hline
\end{tabular}

Notes: See above. 
Table 3: Predictor and outcome means for the autocracy treatment (Africa)

\begin{tabular}{|c|c|c|}
\hline & Uganda 1966 & Synthetic Control \\
\hline Secondary school & 3.5 & 5.78 \\
\hline Population growth & 3.954 & 2.529 \\
\hline Investment share & 0.016 & 0.031 \\
\hline Average Pre-treatment GDP & 205.66 & 208.23 \\
\hline GDP at $\mathrm{T}_{\mathrm{o}}+5$ & 233.71 & 239.87 \\
\hline $\mathrm{GDP}$ at $\mathrm{T}_{\mathrm{o}}+10$ & 200.63 & 335.35 \\
\hline \multirow[t]{2}{*}{ RMSPE } & & 0.000028 \\
\hline & Nigeria 1966 & Synthetic Control \\
\hline Secondary school & 4.5 & 19.027 \\
\hline Population growth & 2.568 & 2.423 \\
\hline Investment share & 0.042 & 0.139 \\
\hline Average Pre-treatment GDP & 230.5 & 230.74 \\
\hline $\mathrm{GDP}$ at $\mathrm{T}_{\mathrm{o}}+5$ & 294 & 278.58 \\
\hline $\mathrm{GDP}$ at $\mathrm{T}_{\mathrm{o}}+10$ & 319 & 295.29 \\
\hline \multirow[t]{2}{*}{ RMSPE } & & 2.781 \\
\hline & Nigeria 1984 & Synthetic Control \\
\hline Secondary school & 17.21 & 28.48 \\
\hline Population growth & 2.809 & 2.277 \\
\hline Investment share & 0.078 & 0.125 \\
\hline Average Pre-treatment GDP & 276.2 & 279.54 \\
\hline GDP at $\mathrm{T}_{\mathrm{o}}+5$ & 246 & 357.99 \\
\hline GDP at $\mathrm{T}_{\mathrm{o}}+10$ & 254 & 410.86 \\
\hline \multirow[t]{2}{*}{ RMSPE } & & 38.980 \\
\hline & Sierra Leone 1971 & Synthetic Control \\
\hline Secondary school & 5.33 & 18.24 \\
\hline Population growth & 1.679 & 2.5140 \\
\hline Investment share & 0.021 & 0.145 \\
\hline Average Pre-treatment GDP & 242.27 & 242.70 \\
\hline $\mathrm{GDP}$ at $\mathrm{T}_{\mathrm{o}}+5$ & 278 & 287.68 \\
\hline GDP at $T_{o}+10$ & 289 & 317.61 \\
\hline \multirow[t]{2}{*}{ RMSPE } & & 5.164 \\
\hline & Lesotho 1970 & Synthetic Control \\
\hline Secondary school & 3.5 & 16.26 \\
\hline Population growth & 1.992 & 2.541 \\
\hline Investment share & 0.033 & 0.141 \\
\hline Average Pre-treatment GDP & 206.8 & 207.70 \\
\hline GDP at $\mathrm{T}_{\mathrm{o}}+5$ & 258 & 251.43 \\
\hline GDP at $T_{o}+10$ & 364 & 281.46 \\
\hline \multirow[t]{2}{*}{ RMSPE } & & 9.642 \\
\hline & Gambia 1994 & Synthetic Control \\
\hline Secondary school & 14.3 & 36.16 \\
\hline Population growth & 3.254 & 2.203 \\
\hline Investment share & 0.043 & 0.125 \\
\hline Average Pre-treatment GDP & 354 & 362.73 \\
\hline GDP at $\mathrm{T}_{\mathrm{o}}+5$ & 365 & 547.65 \\
\hline \multicolumn{3}{|l|}{ GDP at $\mathrm{T}_{\mathrm{o}}+10$} \\
\hline RMSPE & & 30.792 \\
\hline
\end{tabular}

Notes: See above. 
Figure 1 - Trends in real GDP per capita, Greece 1967

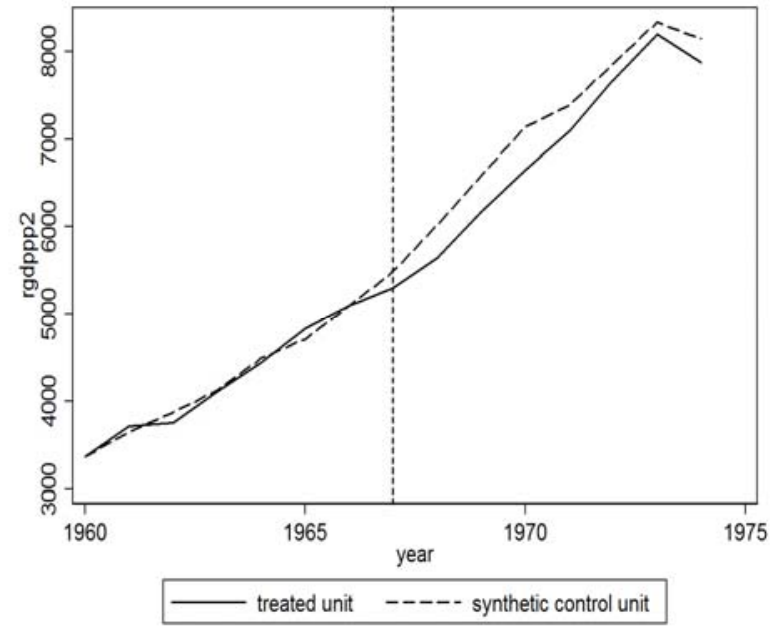

Greece vs. Synthetic Control

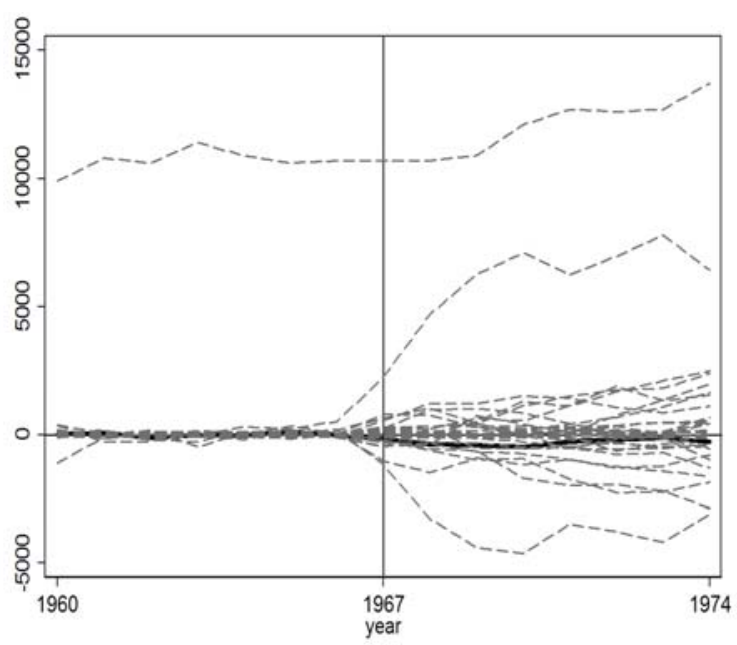

Placebo test

Figure 2 - Trends in real GDP per capita, Philippines 1972

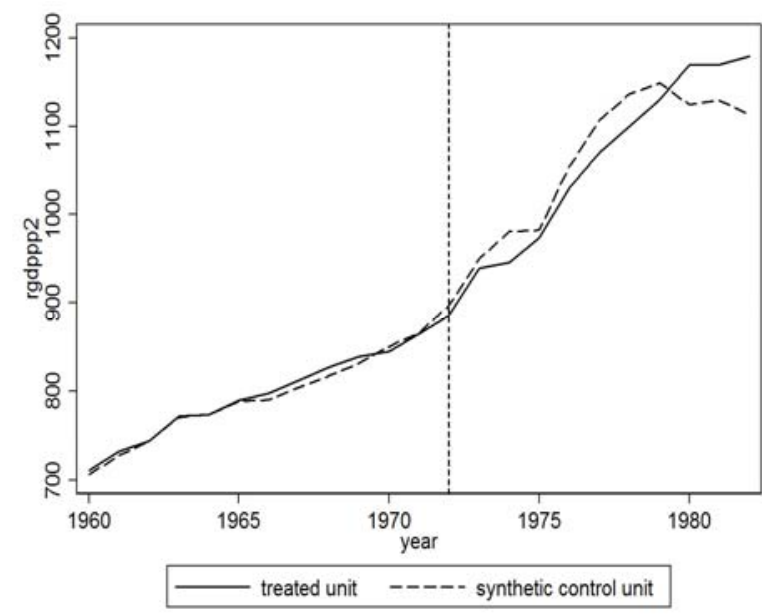

Philippines vs. Synthetic Control

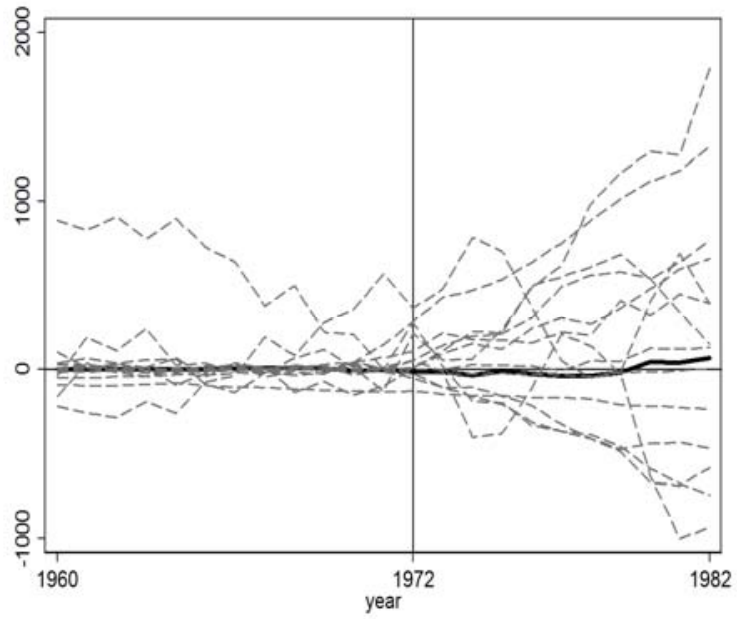

Placebo test

Figure 3 - Trends in real GDP per capita, South Korea 1972

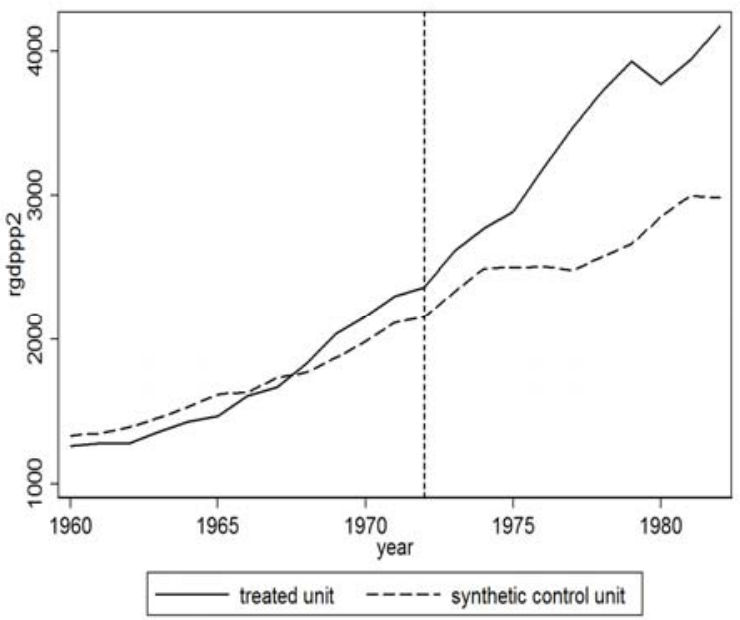

South Korea vs. Synthetic Control

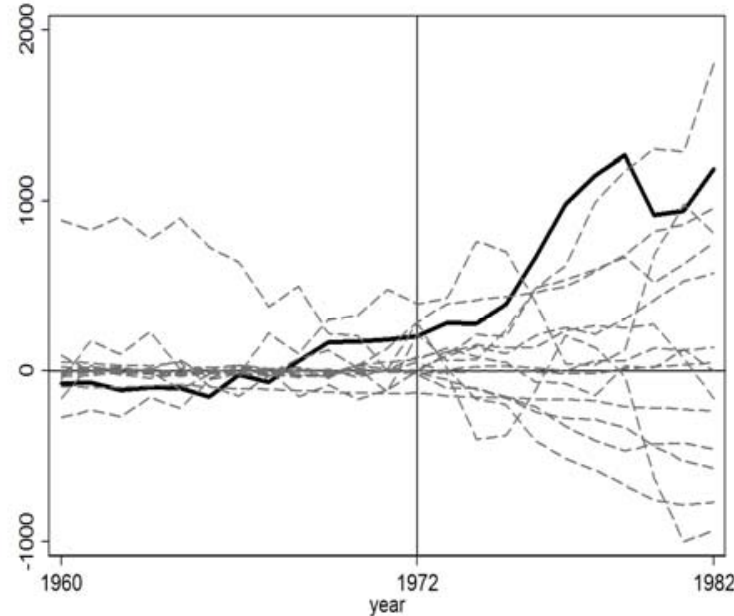

Placebo test 
Figure 4 - Trends in real GDP per capita, Pakistan 1977

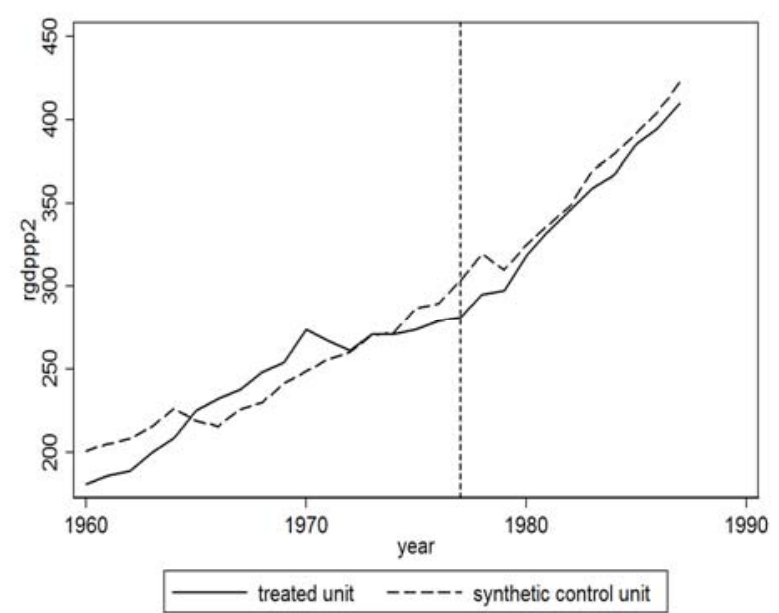

Pakistan vs. Synthetic Control

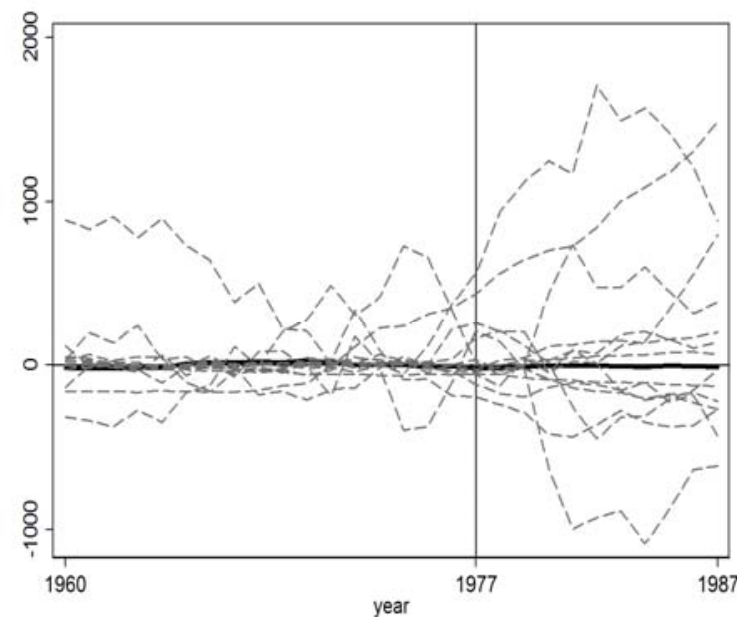

Placebo test

Figure 5 - Trends in real GDP per capita, Panama 1968

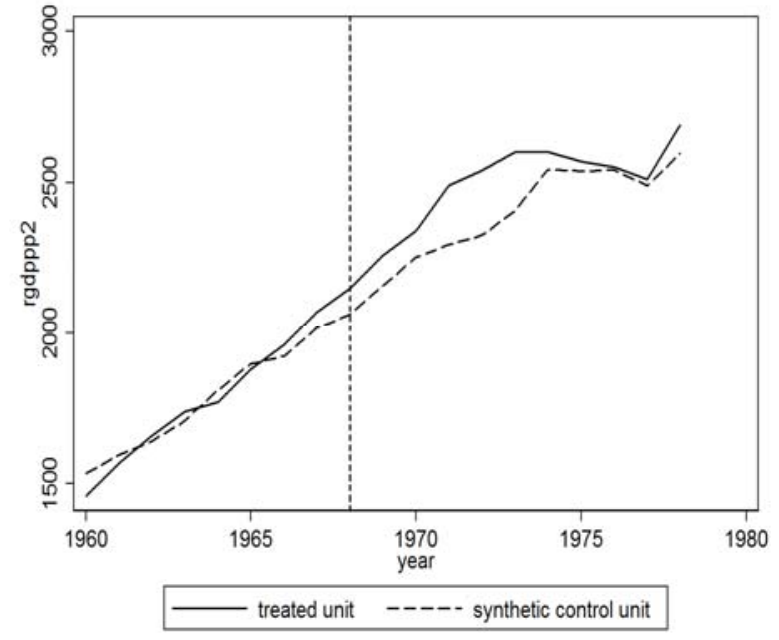

Panama vs. Synthetic Control

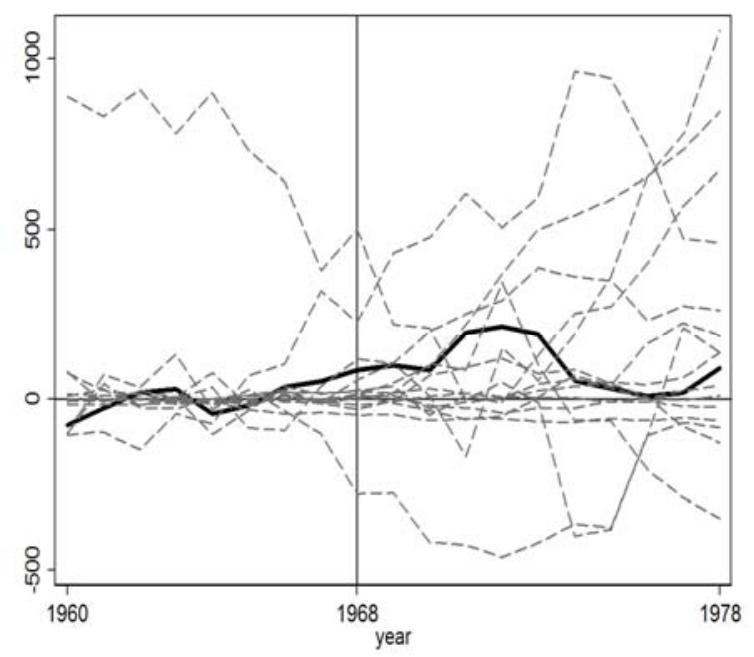

Placebo test

Figure 6 - Trends in real GDP per capita, Peru 1968

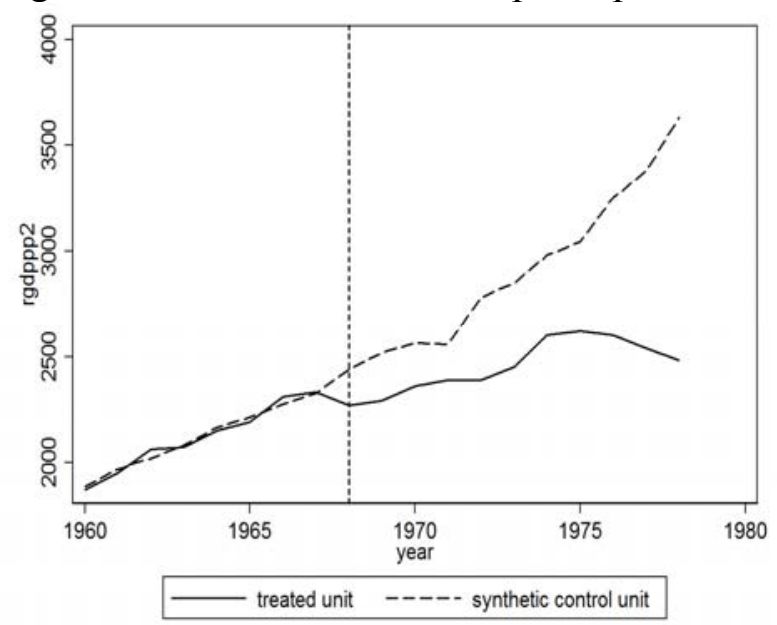

Peru vs. Synthetic Control

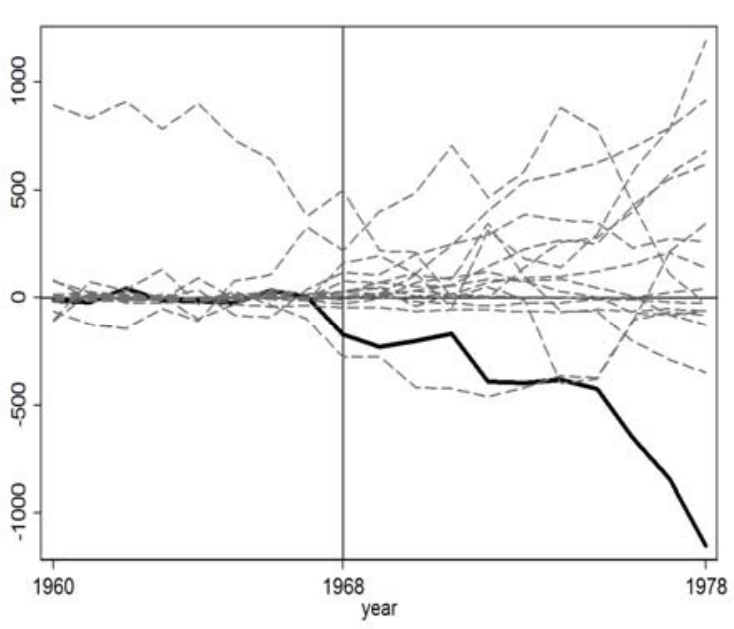

Placebo test 
Figure 7 - Trends in real GDP per capita, Uruguay 1972

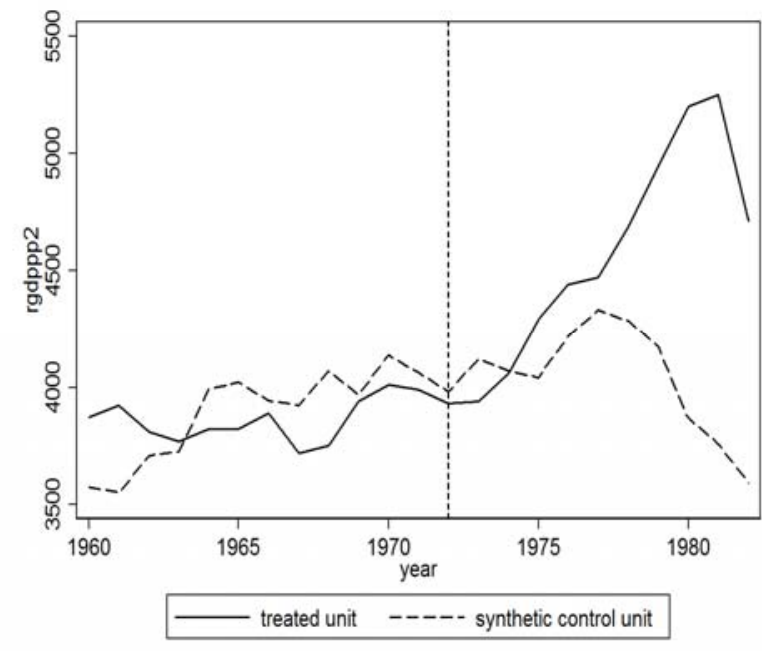

Uruguay vs. Synthetic Control

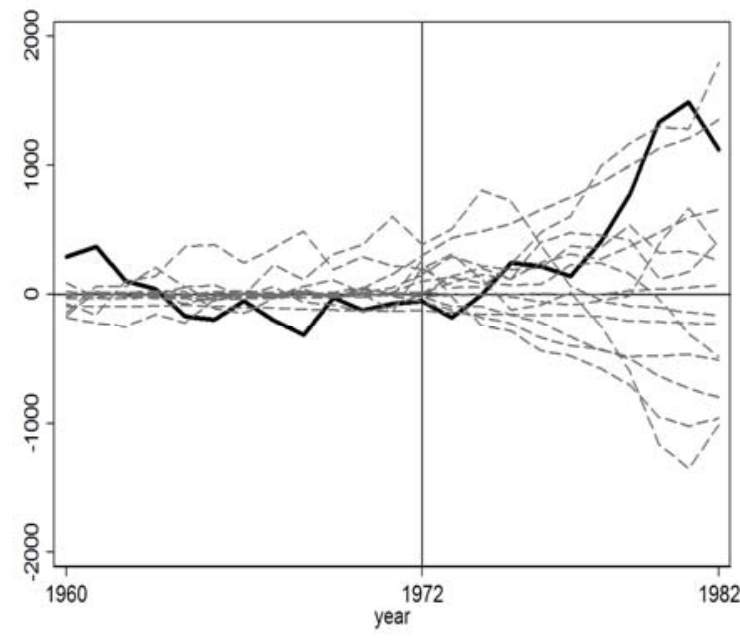

Placebo test

Figure 8 - Trends in real GDP per capita, Chile 1973

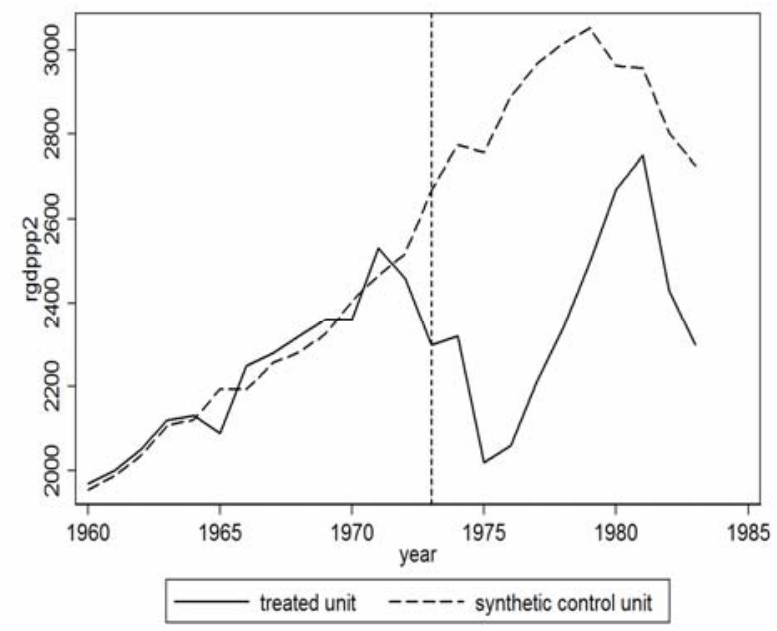

Chile vs. Synthetic Control

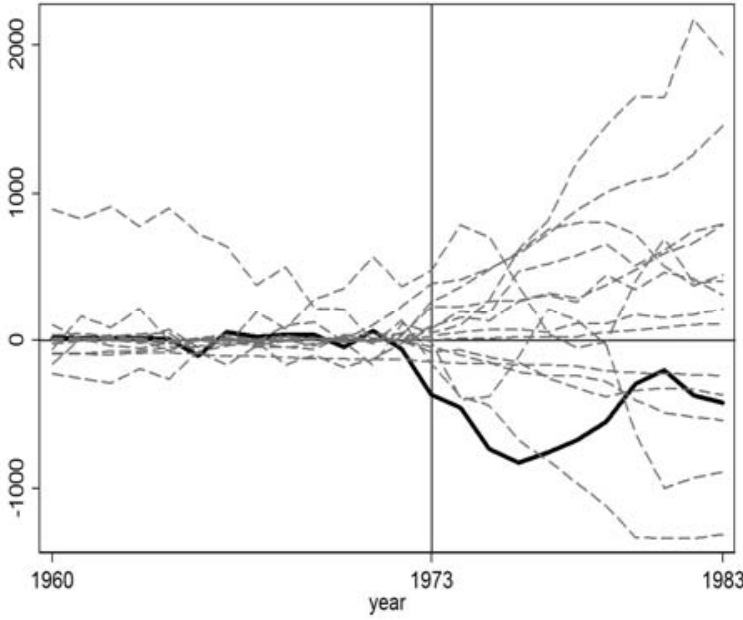

Placebo test

Figure 9 - Trends in real GDP per capita, Uganda 1966

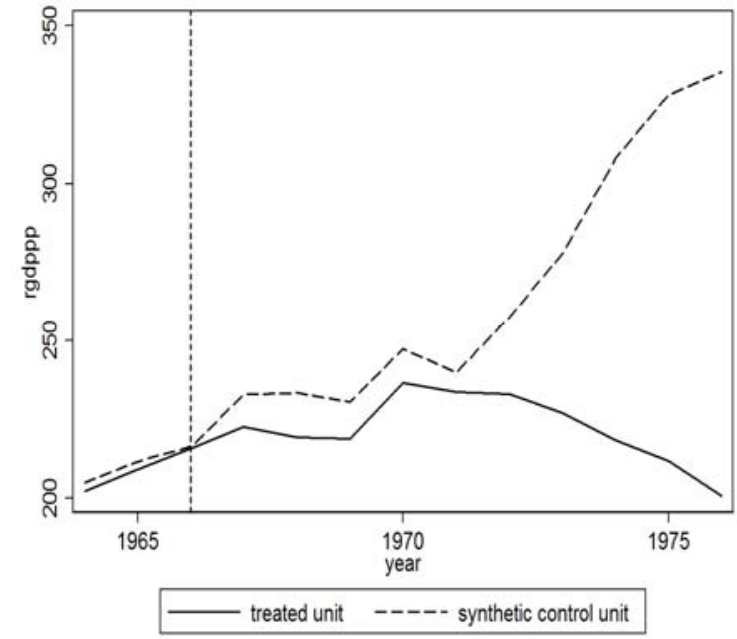

Uganda vs. Synthetic Control

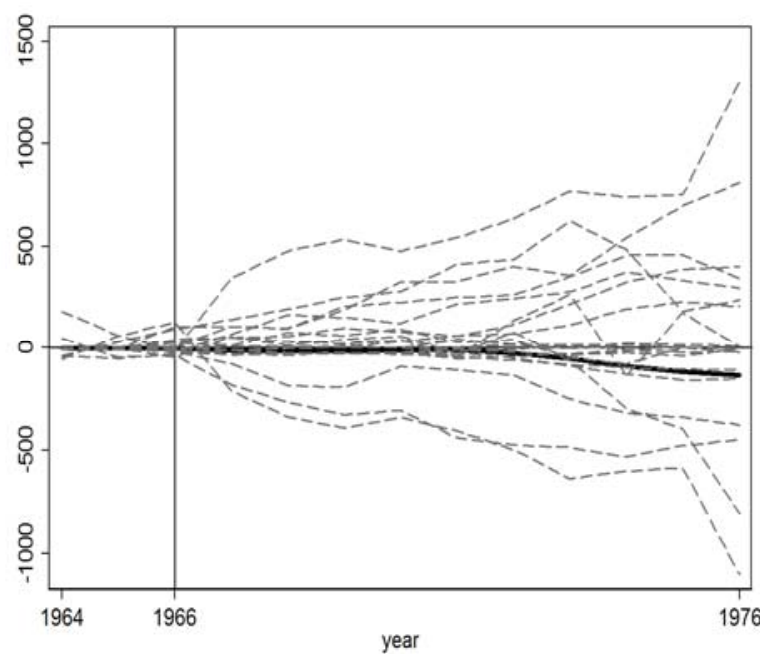

Placebo test 
Figure 10 - Trends in real GDP per capita, Nigeria 1966

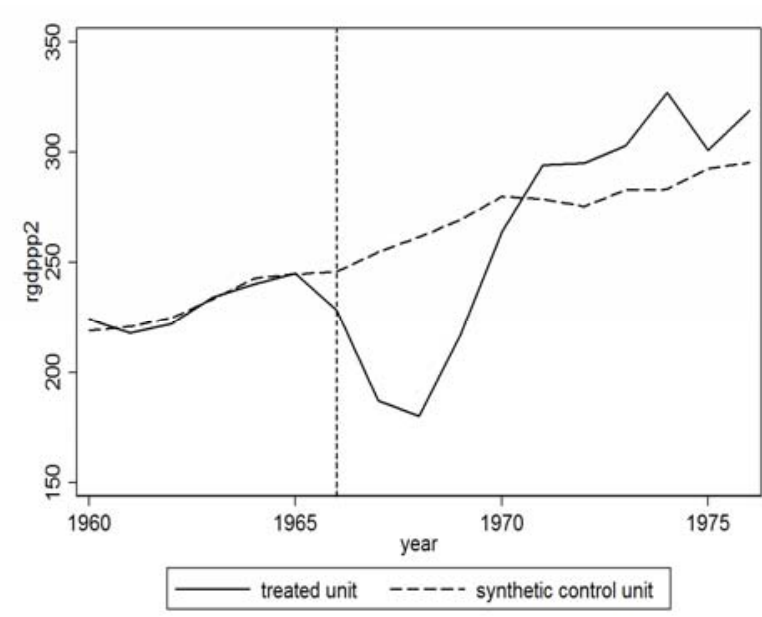

Nigeria 1966 vs. Synthetic Control

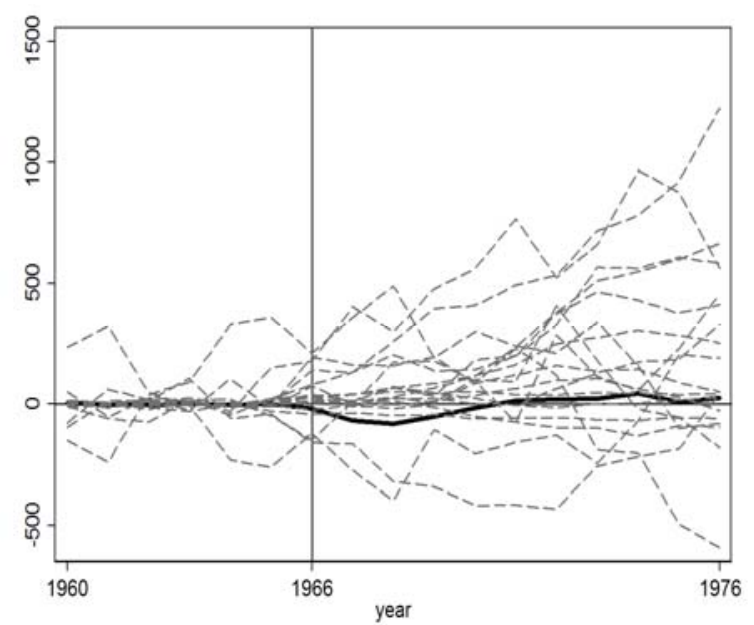

Placebo test

Figure 11 - Trends in real GDP per capita, Nigeria 1984

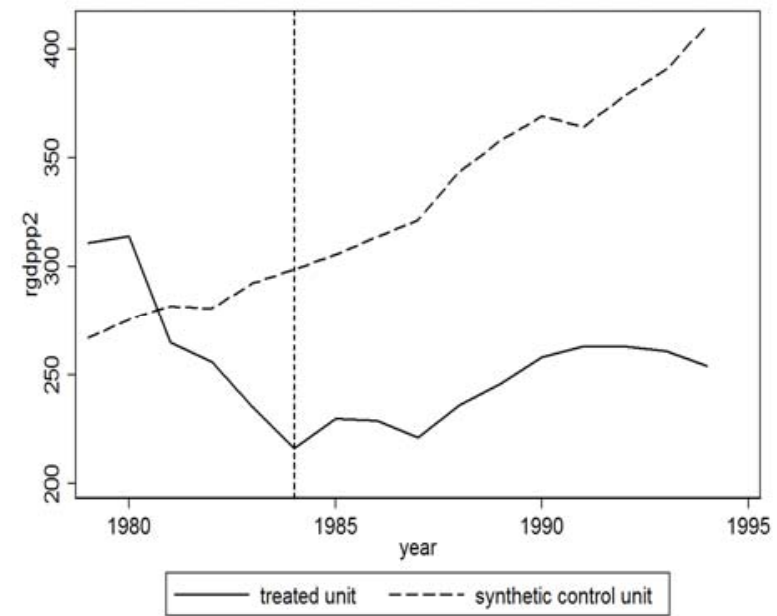

Nigeria 1984 vs. Synthetic Control

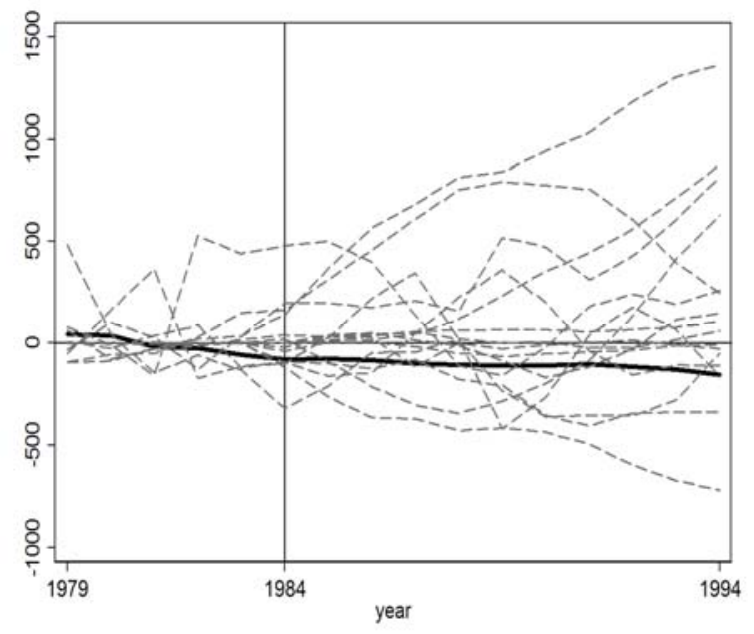

Placebo test

Figure 12 - Trends in real GDP per capita, Sierra Leone 1971

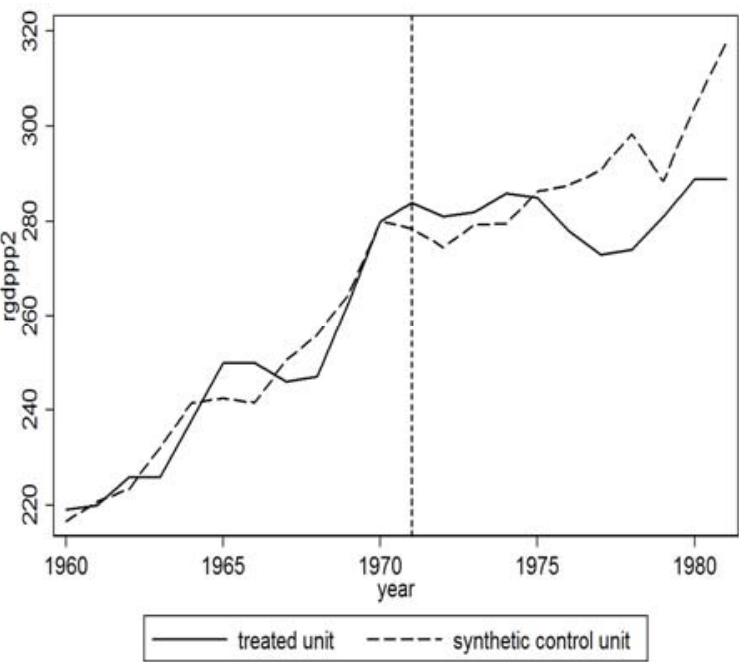

Sierra Leone vs. Synthetic Control

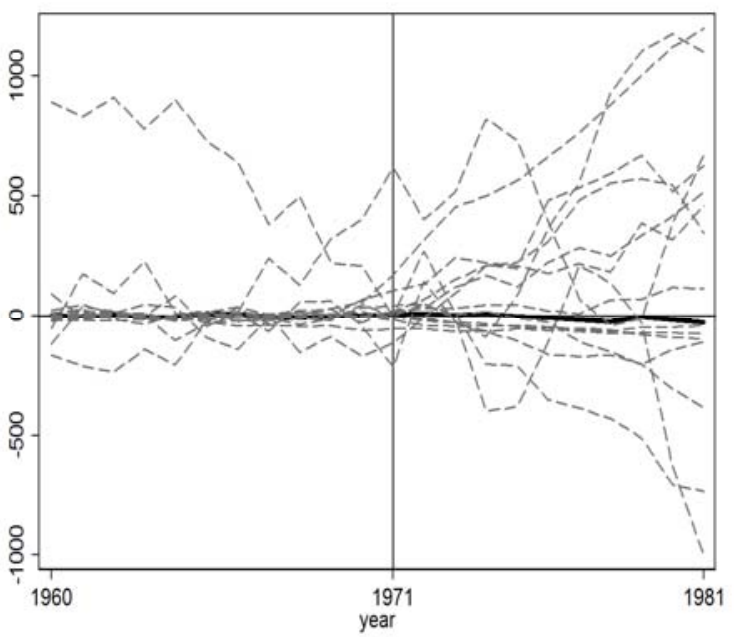

Placebo test 
Figure 13 - Trends in real GDP per capita, Lesotho 1970

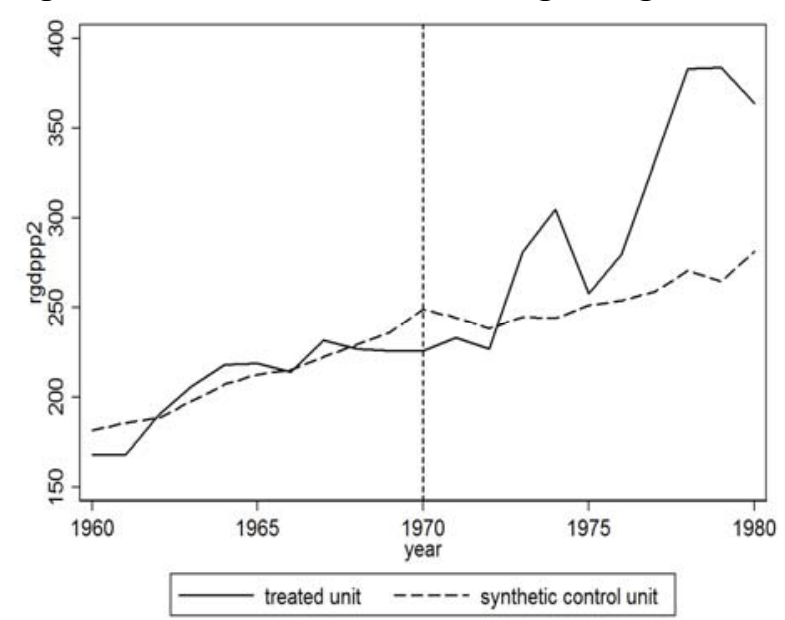

Lesotho vs. Synthetic Control

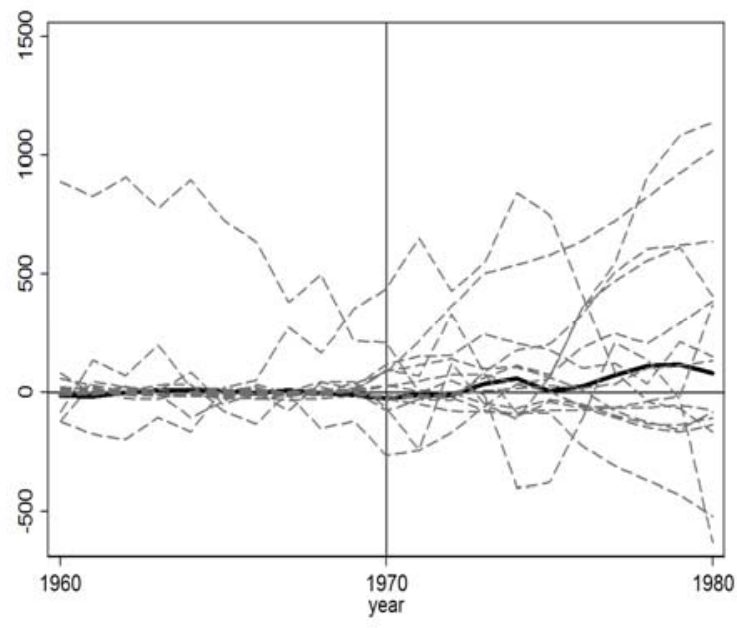

Placebo test

Figure 14 - Trends in real GDP per capita, Gambia 1994

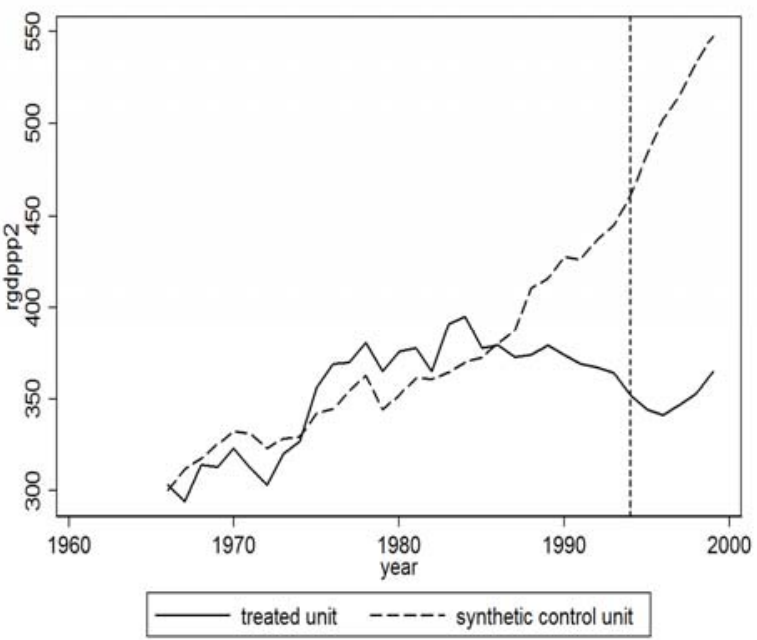

Gambia vs. Synthetic Control

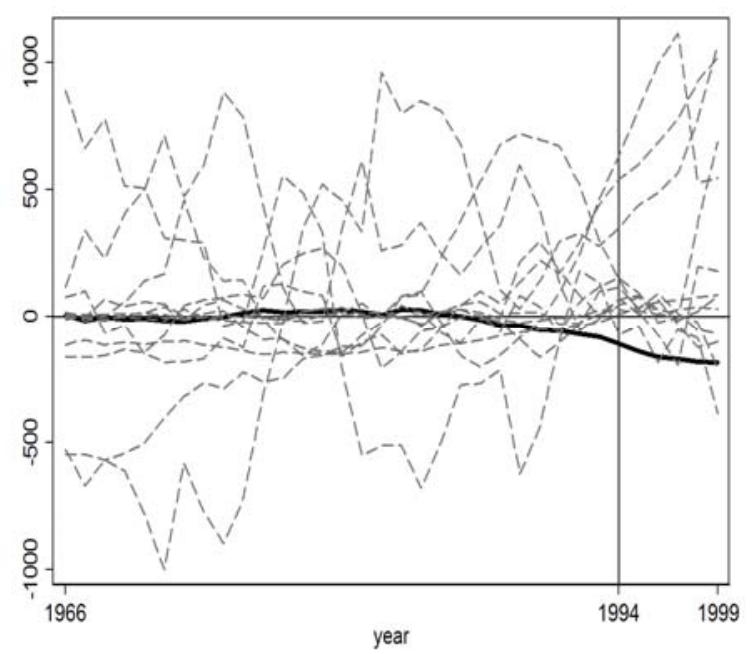

Placebo test 


\section{Appendix I - Transitions to autocracy ${ }^{12}$}

Chile 1973: On September 11, 1973 the government of President Salvador Allende was overthrown by the military in a coup d'état. General Augusto Pinochet assumed power after deposing President Salvador Allende, establishing an anti-communist military dictatorship that ruled until 1990.

Gambia 1994: Until the military coup in 1994, Gambia was ruled by President Dawda Kairaba Jawara, who had been elected five times in a raw. In 1994, the Armed Forces Provisional Ruling Council (AFPRC) deposed the Jawara government and banned opposition political activity. Lieutenant Yahya A.J.J. Jammeh, chairman of the AFPRC, became head of state.

Greece 1967: Rule by the military started in the morning of 21 April 1967 with a coup d'etat led by a group of colonels of the Greek military, and ended in July 1974. "The Regime of the Colonels" refers to a series of right-wing military governments that ruled Greece from 1967 to 1974.

Lesotho 1970: In January 1970 the ruling Basotho National Party (BNP) lost the first postindependence general elections 36. Prime Minister Leabua Jonathan refused to cede power to the Basotho Congress Party (BCP), declared himself Tona Kholo, and imprisoned the BCP leadership.

Nigeria 1966: The first military coup was in January and led by a collection of young leftists under Major Emmanuel Ifeajuna and Chukwuma Kaduna Nzeogwu. This coup was counteracted by another successful plot, which allowed Lt Colonel Yakubu Gowon to become head of state.

Nigeria 1984: A new constitution was approved in 1977, and in 1979 Shehu Shagari won democratic elections. A military coup in 1983 established the High Military Council as new ruling body.

Panama 1968: A military coup overthrew the elected government headed by Arnulfo Arias Madrid. Generale Omar Torrijos exerted power over the junta until his death in 1981 in an alleged plane accident.

Pakistan 1977: In 1977 Zulfikar Ali Bhutto enjoyed an unprecedented victory and became Prime Minister, and then a staged military coup headed by Zia-ul-Haq apprehended him on issues of vote-rigging and banned all political activities leading the nation into a martial law.

Peru 1968: The elected government of President Fernando Belaunde Terry was deposed by coup; he was succeeded by General Juan Velasco Alvardo.

Philippines 1972: Barred from seeking a third term, President Ferdinand Marcos declared martial law on September 21, 1972, under the guise of increased political instability and resurgent Communist and Muslim insurgencies, and ruled the country by decree.

\footnotetext{
${ }^{12}$ The source is Wikipedia, accessed on November $4^{\text {th }}, 2009$.
} 
Sierra Leone 1971: After a closely contested general elections in March 1967, Siaka Stevens, candidate of the All People's Congress (APC) was appointed new prime minister. He was subject to a number of coups. On April 19, 1971, parliament declared Sierra Leone a Republic. Siaka Stevens' title was changed from Prime Minister to President. Guinean troops requested by Stevens to support his government were in the country from 1971 to 1973 . The opposition boycotted the 1973 general election.

South Korea 1972: On December 6, 1971, Park declared a state of national emergency. On July 4 of the following year, he announced plans for reunification with North Korea. Park declared martial law in October 1972, dissolving the National Assembly. The Fourth Republic began with the adoption of the Yusin Constitution in November 1972. This new constitution gave Park effective control over the parliament.

Uganda 1966: In 1966, Milton Obote overthrew the king Edward Muteesa II, the President and Commander in Chief of the armed forces. A Parliament dominated by the Uganda People's Congress changed the constitution, and Obote became president. The elections were suspended, ushering in an era of coups and counter-coups, which would last until the mid1980s. Obote was deposed twice from office, both times by military coup.

Uruguay 1972: President Jorge Pacheco declared a state of emergency in 1968, followed by a further suspension of civil liberties in 1972 by his successor, President Juan María Bordaberry. After defeating the Tupamaros, the military seized power in 1973. In 1980, the army forces proposed a change in the constitution that would be passed with a referendum. The "No" to the reform won the vote with $57.2 \%$ of the votes. In 1984 , massive protests against military rule broke out, and the country returned to civilian rule with national elections held later in the same year. 


\section{Appendix II - Treated countries and donor pools for the synthetic control experiments}

Greece 1967

Potential controls

Philippines 1972

Potential controls

South Korea 1972

Potential controls

\section{Pakistan 1977}

Potential controls

\section{Panama 1968}

Potential controls

\section{Peru 1968}

Potential controls

\section{Uruguay 1972}

Potential controls

\section{Chile 1973}

Potential controls

\section{Uganda 1966}

Potential controls

\section{Nigeria 1966}

Potential controls
Australia, Austria, Belgium, Denmark, Finland, France, Iceland, Ireland, Israel, Italy, Japan, Luxembourg, Netherlands, New Zealand, Norway, Sweden, Switzerland, United Kingdom, United States, Fiji, India, Malaysia, Papua New Guinea, Sri Lanka, Botswana, Colombia, Costa Rica, Jamaica, Mauritius, South Africa, Zimbabwe Trinidad \& Tobago, Venezuela.

Fiji, India, Malaysia, Papua New Guinea, Sri Lanka, Botswana, Colombia, Costa Rica, Jamaica, Mauritius, South Africa, Zimbabwe Trinidad \& Tobago, Venezuela.

Fiji, India, Malaysia, Papua New Guinea, Sri Lanka, Botswana, Colombia, Costa Rica, Jamaica,Trinidad \& Tobago, Mauritius, South Africa, Zimbabwe, Venezuela.

Fiji, India, Malaysia, Papua New Guinea, Sri Lanka, Botswana, Colombia, Costa Rica, Jamaica, Mauritius, Trinidad \& Tobago, Venezuela, South Africa, Zimbabwe.

Colombia, Costa Rica, Jamaica, Trinidad \& Tobago, Venezuela, Mauritius, South Africa, India, Malaysia, Papua New Guinea, Sri Lanka, Botswana, Pakistan, Zimbabwe, Fiji.

Colombia, Costa Rica, Jamaica, Trinidad \& Tobago, Venezuela, India, Malaysia, Fiji, Papua New Guinea, Sri Lanka, Botswana, Mauritius, South Africa, Pakistan, Zimbabwe.

Colombia, Costa Rica, Jamaica, Trinidad \& Tobago, Venezuela, India, Malaysia, Zimbabwe, Papua New Guinea, Sri Lanka, Botswana, Mauritius, South Africa, Fiji.

Colombia, Costa Rica, Jamaica, Trinidad \& Tobago, Venezuela, India, Malaysia, Papua New Guinea, Sri Lanka, Botswana, Mauritius,South Africa, Zimbabwe,Fiji.

Botswana, Mauritius, South Africa, Zimbabwe, India, Malaysia, Sri Lanka, Colombia, Costa Rica, Jamaica, Venezuela, Uruguay, Philippines, South Korea, Chile, Pakistan, Fiji,Trinidad \& Tobago,Papua New Guinea,Gambia.

Botswana, Mauritius, South Africa, Zimbabwe, India, Malaysia, Papua New Guinea, Sri Lanka, Colombia, Costa Rica, Jamaica, Trinidad \& Tobago, Venezuela, Uruguay, Philippines, South Korea, Chile, Pakistan, Fiji. 
Sierra Leone 1971

Potential controls

\section{Lesotho 1970}

Potential controls

\section{Nigeria 1984}

Potential controls

\section{Gambia 1994}

Potential controls
Botswana, Mauritius, South Africa, Zimbabwe, India, Malaysia, Papua New Guinea, Sri Lanka, Colombia, Costa Rica, Jamaica, Trinidad \& Tobago, Venezuela, Pakistan, Fiji.

Botswana, Mauritius, South Africa, Zimbabwe, India, Malaysia, Papua New Guinea, Sri Lanka, Colombia, Costa Rica, Jamaica, Trinidad \& Tobago, Venezuela, Pakistan, Fiji.

Botswana, Mauritius, South Africa, India, Malaysia, Papua New Guinea, Sri Lanka, Colombia, Costa Rica, Jamaica, Trinidad \& Tobago, Venezuela, Thailand, Dominican Republic, Ecuador, Peru.

Botswana, Mauritius, South Africa, India, Malaysia, Papua New Guinea, Sri Lanka, Colombia, Costa Rica, Jamaica, Trinidad \& Tobago,Venezuela. 
Appendix III - Control countries with weight higher than 0.02 in the synthetic control

$\underline{A S I A}$

PHILIPPINES 1972

Synth. Control

Costa Rica

India

Malaysia

Mauritius

Venezuela

SOUTH KOREA 1972

Synth. Control

Botswana

South Africa

PAKISTAN 1977

Synth. Control

Botswana

India

Papua N. Guinea

\section{$O E C D$}

GREECE 1967

Synth. Control

Papua N. Guinea

Japan

Jamaica

South Africa

New Zealand
$\underline{L A A M}$

PANAMA 1968

Synth. Control

0.115

0.608

0.124

0.116

0.032

0.602

0.398

0.057

0.920

0.023

0.415

0.288

0.214

0.052

0.031
PERU 1968

Synth. Control

Costa Rica

Malaysia

South Africa

Trinidad \& Tob.

URUGUAY 1972

Synth. Control

Mauritius

Venezuela

CHILE 1973

Synth. Control

Costa Rica

Fiji

0.391

0.052

0.312

Mauritius

0.150

South Africa

Venezuela
$\underline{A F R I C A}$

UGANDA 1966

Synth. Control

Botswana

0.127

Gambia

0.784

India

0.030

NIGERIA 1966

Synth. Control

Costa Rica $\quad 0.021$

India $\quad 0.608$

Pakistan $\quad 0.371$

SIERRA LEONE 1971

Synth. Control

India $\quad 0.556$

Pakistan $\quad 0.378$

Zimbabwe $\quad 0.061$

LESOTHO 1970

Synth. Control

India 0.398

Pakistan $\quad 0.601$

NIGERIA 1984

Synth. Control

India

0.983

GAMBIA 1994

Synth. Control

India

0.969 


\section{References}

Abadie, A., Diamond, A., and Hainmueller, J. (2010). Synthetic Control Methods for Comparative Case Studies: Estimating the Effect of California's Tobacco Control Program, Journal of the American Statistical Association, forthcoming.

Abadie, A., and Gardeazabal, J. (2003). The Economic Costs of Conflict: A Case Study of the Basque Country, American Economic Review, 93, 113-132.

Acemoglu, D., Johnson, S., Robinson, J. and Yared, P. (2008). Income and Democracy, American Economic Review, 98, 808-842.

Acemoglu, D., Johnson, S., Robinson, J. and Yared, P. (2010). Reevaluating the Modernization Hypothesis, Journal of Monetary Economics, forthcoming.

Acemoglu, D., and Robinson, J. (2005). Economic Origins of Dictatorship and Democracy, Cambridge: Cambridge University Press.

Acemoglu, D., Ticchi, D. and Vindigni, A. (2010). A Theory of Military Dictatorships, American Economic Journal: Macroeconomics, 2, 1-42.

Aghion, P., Alesina, A., Trebbi, F. (2007). Democracy, Technology, and Growth, mimeo.

Barro R.J. (1996). Democracy and Growth, Journal of Economic Growth, 1, 1-27.

Besley, T., and Kudamatsu, M. (2008). Making Autocracy Work, in Helpman, E. (ed.) Institutions and Economic Performance, Cambridge: Harvard University Press.

Billmeier, A. and Nannicini, T. (2009a). Trade Openness and Growth: Pursuing Empirical Glasnost, IMF Staff Papers, 56, 447-475.

Billmeier, A. and Nannicini, T. (2009b). Yes You Can, Can't You? A Statistical Comparison of Economic Liberalizations Around the World, IGIER Working Paper n. 352.

Bollen, K.A. (1960). Political Democracy: Conceptual and Measurement Traps, Studies in Comparative International Development, 7-24.

de Haan, J., and Siermann, C.L.J. (1995). New Evidence on the Relationship between Democracy and Economic Growth, Public Choice, 86, 175-198.

Durham, J.B. (1999). Economic Growth and Political Regimes, Journal of Economic Growth, 4, 81-111.

Forrest, T. (1992). Politics and Economic Development in Nigeria, Boulder-Oxford: Westview Press.

Giavazzi, F., and Tabellini, G. (2005). Economic and Political Liberalizations, Journal of Monetary Economics, 52, 1297-1330.

Grossman, H.I., and Noh, S.J. (1994). Proprietary Public Finance and Economic Welfare, Journal of Public Economics, 53, 187-204.

Marshall, M.G, and Jaggers, K. (2009). Polity IV Project. Political Regime Characteristics and Transitions, 1800-2008. At: http://www.systemicpeace.org/polity/polity4.htm

McGuire, M.C., and Olson, M., Jr. (1996). The Economics of Autocracy and Majority Rule: The Invisible Hand and the Use of Force, Journal of Economic Literature, 34, 72-96.

Minier, J.A. (1998). Democracy and Growth: Alternative Approaches, Journal of Economic Growth, 3, 241-266.

Overland, J., Simons, K. and Spagat, M. (2005). Political Instability and Growth in Dictatorships, Public Choice, 25, 445-470.

Papaioannou, E., and Siourounis, G. (2008a). Democratization and Growth, Economic Journal, 118, 1520-1551.

Papaioannou, E., and Siourounis, G. (2008b). Economic and Social Factors Driving the Third Wave of Democratization, Journal of Comparative Economics, 36, 365-387.

Persson, T., and Tabellini, G. (2006). Democracy and Development: The Devil in the Details, American Economic Review Papers and Proceedings, 96, 319-324. 
Persson, T., and Tabellini, G. (2008). The Growth Effects of Democracy: Is It Heterogeneous and How Can It Be Estimated? In: Helpman, E. (ed.), Institutions and Economic Performance, Cambridge: Harvard University Press.

Persson, T., and Tabellini, G. (2009). Democratic Capital: the Nexus of Political and Economic Change, American Economic Journal: Macroeconomics, 1, 88-126.

Przeworski, A., Limongi, F., (1993). Political regimes and economic growth, Journal of Economic Perspective, 7, 51-69.

Przeworski, A., M. Alvarez, J. Cheibub, and F. Limongi, (2000). Democracy and Development: Political Institutions and Well-Being in the World 1900-1950, Cambridge University Press.

Rodrick, D. and Wacziarg, R. (2005). Do Democratic Transitions Produce Bad Economic Outcomes? American Economic Review Papers and Proceedings, 95, 50-55.

Sachs, J.D. and Warner, A.M. (2001). The curse of natural resources, European Economic Review, 45, 827-838.

Sala-i-Martin, X. and Subramanian, A. (2003). Addressing the Natural Resource Curse: An Illustration from Nigeria, NBER Working Paper n. 9804.

Tavares, J. and Wacziarg, R. (2001). How Democracy Affects Growth, European Economic Review, 45, 1341-1378. 


\section{CESifo Working Paper Series}

for full list see www.cesifo-group.org/wp

(address: Poschingerstr. 5, 81679 Munich, Germany, office@cesifo.de)

2905 Mikael Priks, The Effect of Surveillance Cameras on Crime: Evidence from the Stockholm Subway, December 2009

2906 Xavier Vives, Asset Auctions, Information, and Liquidity, January 2010

2907 Edwin van der Werf, Unilateral Climate Policy, Asymmetric Backstop Adoption, and Carbon Leakage in a Two-Region Hotelling Model, January 2010

2908 Margarita Katsimi and Vassilis Sarantides, Do Elections Affect the Composition of Fiscal Policy?, January 2010

2909 Rolf Golombek, Mads Greaker and Michael Hoel, Climate Policy without Commitment, January 2010

2910 Sascha O. Becker and Ludger Woessmann, The Effect of Protestantism on Education before the Industrialization: Evidence from 1816 Prussia, January 2010

2911 Michael Berlemann, Marco Oestmann and Marcel Thum, Demographic Change and Bank Profitability. Empirical Evidence from German Savings Banks, January 2010

2912 Øystein Foros, Hans Jarle Kind and Greg Shaffer, Mergers and Partial Ownership, January 2010

2913 Sean Holly, M. Hashem Pesaran and Takashi Yamagata, Spatial and Temporal Diffusion of House Prices in the UK, January 2010

2914 Christian Keuschnigg and Evelyn Ribi, Profit Taxation and Finance Constraints, January 2010

2915 Hendrik Vrijburg and Ruud A. de Mooij, Enhanced Cooperation in an Asymmetric Model of Tax Competition, January 2010

2916 Volker Meier and Martin Werding, Ageing and the Welfare State: Securing Sustainability, January 2010

2917 Thushyanthan Baskaran and Zohal Hessami, Globalization, Redistribution, and the Composition of Public Education Expenditures, January 2010

2918 Angel de la Fuente, Testing, not Modelling, the Impact of Cohesion Support: A Theoretical Framework and some Preliminary Results for the Spanish Regions, January 2010

2919 Bruno S. Frey and Paolo Pamini, World Heritage: Where Are We? An Empirical Analysis, January 2010 
2920 Susanne Ek and Bertil Holmlund, Family Job Search, Wage Bargaining, and Optimal Unemployment Insurance, January 2010

2921 Mariagiovanna Baccara, Allan Collard-Wexler, Leonardo Felli and Leeat Yariv, Gender and Racial Biases: Evidence from Child Adoption, January 2010

2922 Kurt R. Brekke, Roberto Cellini, Luigi Siciliani and Odd Rune Straume, Competition and Quality in Regulated Markets with Sluggish Demand, January 2010

2923 Stefan Bauernschuster, Oliver Falck and Niels Große, Can Competition Spoil Reciprocity? - A Laboratory Experiment, January 2010

2924 Jerome L. Stein, A Critique of the Literature on the US Financial Debt Crisis, January 2010

2925 Erkki Koskela and Jan König, Profit Sharing, Wage Formation and Flexible Outsourcing under Labor Market Imperfection, January 2010

2926 Gabriella Legrenzi and Costas Milas, Spend-and-Tax Adjustments and the Sustainability of the Government’s Intertemporal Budget Constraint, January 2010

2927 Piero Gottardi, Jean Marc Tallon and Paolo Ghirardato, Flexible Contracts, January 2010

2928 Gebhard Kirchgässner and Jürgen Wolters, The Role of Monetary Aggregates in the Policy Analysis of the Swiss National Bank, January 2010

2929 J. Trent Alexander, Michael Davern and Betsey Stevenson, Inaccurate Age and Sex Data in the Census PUMS Files: Evidence and Implications, January 2010

2930 Stefan Krasa and Mattias K. Polborn, Competition between Specialized Candidates, January 2010

2931 Yin-Wong Cheung and Xingwang Qian, Capital Flight: China’s Experience, January 2010

2932 Thomas Hemmelgarn and Gaetan Nicodeme, The 2008 Financial Crisis and Taxation Policy, January 2010

2933 Marco Faravelli, Oliver Kirchkamp and Helmut Rainer, Social Welfare versus Inequality Concerns in an Incomplete Contract Experiment, January 2010

2934 Mohamed El Hedi Arouri and Christophe Rault, Oil Prices and Stock Markets: What Drives what in the Gulf Corporation Council Countries?, January 2010

2935 Wolfgang Lechthaler, Christian Merkl and Dennis J. Snower, Monetary Persistence and the Labor Market: A New Perspective, January 2010

2936 Klaus Abberger and Wolfgang Nierhaus, Markov-Switching and the Ifo Business Climate: The Ifo Business Cycle Traffic Lights, January 2010 
2937 Mark Armstrong and Steffen Huck, Behavioral Economics as Applied to Firms: A Primer, February 2010

2938 Guglielmo Maria Caporale and Alessandro Girardi, Price Formation on the EuroMTS Platform, February 2010

2939 Hans Gersbach, Democratic Provision of Divisible Public Goods, February 2010

2940 Adam Isen and Betsey Stevenson, Women's Education and Family Behavior: Trends in Marriage, Divorce and Fertility, February 2010

2941 Peter Debaere, Holger Görg and Horst Raff, Greasing the Wheels of International Commerce: How Services Facilitate Firms’ International Sourcing, February 2010

2942 Emanuele Forlani, Competition in the Service Sector and the Performances of Manufacturing Firms: Does Liberalization Matter?, February 2010

2943 James M. Malcomson, Do Managers with Limited Liability Take More Risky Decisions? An Information Acquisition Model, February 2010

2944 Florian Englmaier and Steve Leider, Gift Exchange in the Lab - It is not (only) how much you give ..., February 2010

2945 Andrea Bassanini and Giorgio Brunello, Barriers to Entry, Deregulation and Workplace Training: A Theoretical Model with Evidence from Europe, February 2010

2946 Jan-Emmanuel De Neve, James H. Fowler and Bruno S. Frey, Genes, Economics, and Happiness, February 2010

2947 Camille Cornand and Frank Heinemann, Measuring Agents' Reaction to Private and Public Information in Games with Strategic Complementarities, February 2010

2948 Roel Beetsma and Massimo Giuliodori, Discretionary Fiscal Policy: Review and Estimates for the EU, February 2010

2949 Agnieszka Markiewicz, Monetary Policy, Model Uncertainty and Exchange Rate Volatility, February 2010

2950 Hans Dewachter and Leonardo Iania, An Extended Macro-Finance Model with Financial Factors, February 2010

2951 Helmuth Cremer, Philippe De Donder and Pierre Pestieau, Education and Social Mobility, February 2010

2952 Zuzana Brixiová and Balázs Égert, Modeling Institutions, Start-Ups and Productivity during Transition, February 2010

2953 Roland Strausz, The Political Economy of Regulatory Risk, February 2010 
2954 Sanjay Jain, Sumon Majumdar and Sharun W. Mukand, Workers without Borders? Culture, Migration and the Political Limits to Globalization, February 2010

2955 Andreas Irmen, Steady-State Growth and the Elasticity of Substitution, February 2010

2956 Bengt-Arne Wickström, The Optimal Babel - An Economic Framework for the Analysis of Dynamic Language Rights, February 2010

2957 Stefan Bauernschuster and Helmut Rainer, From Politics to the Family: How Sex-Role Attitudes Keep on Diverging in Reunified Germany, February 2010

2958 Patricia Funk and Christina Gathmann, How do Electoral Systems Affect Fiscal Policy? Evidence from State and Local Governments, 1890 to 2005, February 2010

2959 Betsey Stevenson, Beyond the Classroom: Using Title IX to Measure the Return to High School Sports, February 2010

2960 R. Quentin Grafton, Tom Kompas and Ngo Van Long, Biofuels Subsidies and the Green Paradox, February 2010

2961 Oliver Falck, Stephan Heblich, Alfred Lameli and Jens Suedekum, Dialects, Cultural Identity, and Economic Exchange, February 2010

2962 Bård Harstad, The Dynamics of Climate Agreements, February 2010

2963 Frederick van der Ploeg and Cees Withagen, Is There Really a Green Paradox?, February 2010

2964 Ingo Vogelsang, Incentive Regulation, Investments and Technological Change, February 2010

2965 Jan C. van Ours and Lenny Stoeldraijer, Age, Wage and Productivity, February 2010

2966 Michael Hoel, Climate Change and Carbon Tax Expectations, February 2010

2967 Tommaso Nannicini and Roberto Ricciuti, Autocratic Transitions and Growth, February 2010 